\title{
Tracking geothermal anomalies along a crustal fault using (U-Th)/He apatite thermochronology and rare-earth element (REE) analyses: the example of the Têt fault (Pyrenees, France)
}

\author{
Gaétan Milesi $^{1}$, Patrick Monié ${ }^{1}$, Philippe Münch ${ }^{1}$, Roger Soliva $^{1}$, Audrey Taillefer ${ }^{1}$, Olivier Bruguier ${ }^{1}$, \\ Mathieu Bellanger ${ }^{2}$, Michaël Bonno ${ }^{1}$, and Céline Martin ${ }^{1}$ \\ ${ }^{1}$ Géosciences Montpellier, Université de Montpellier, CNRS, Université des Antilles, Montpellier, France \\ ${ }^{2}$ TLS Geothermics, 91 chemin de Gabardie, 31200 Toulouse, France
}

Correspondence: Gaétan Milesi (gaetan.milesi@umontpellier.fr)

Received: 15 April 2020 - Discussion started: 23 April 2020

Revised: 30 June 2020 - Accepted: 28 July 2020 - Published: 14 September 2020

\begin{abstract}
The Têt fault is a major crustal-scale fault in the eastern Pyrenees (France) along which 29 hot springs emerge, mainly within the footwall damage zone of the fault. In this study, $(\mathrm{U}-\mathrm{Th}) / \mathrm{He}$ apatite $(\mathrm{AHe})$ thermochronology is used in combination with rare-earth element (REE) analyses in order to investigate the imprint of hydrothermal activity around two main hot spring clusters (Thuès-les-Bains and St Thomas) and between them. The main goal is to better define the geometry and intensity of the recent thermal anomalies along the fault and to compare them with previous results from numerical modelling. This study displays 99 new AHe ages and 63 REE analyses on single apatite grains from samples collected in the hanging wall (18 to $43 \mathrm{Ma}$ ) and footwall (8 to $26 \mathrm{Ma}$ ) of the Têt fault. In the footwall, the results reveal AHe age resetting and apatite REE depletion due to hydrothermal circulation along the Têt fault damage zone, near the two hot spring clusters, and also in areas lacking present-day geothermal surface manifestation. These age resettings and element depletions are more pronounced around the Thuès-les-Bains hot spring cluster and are spatially restricted to a limited volume of the damage zone. Outside this damage zone, new modelling of thermochronological data specifies the thermal evolution of the massifs. The footwall model suggests the succession of two main phases of cooling: between 30 and $24 \mathrm{Ma}$ and a second one around $10 \mathrm{Ma}$. In the hanging wall, little evidence of hydrothermal imprint on AHe ages and REE signatures has been found, and thermal modelling records a single cooling phase at 35-
\end{abstract}

$30 \mathrm{Ma}$. Low-temperature thermochronology combined with REE analyses allows us to identify the spatial extent of a recent geothermal perturbation related to hydrothermal flow along a master fault zone in the eastern Pyrenees, opens new perspectives to constrain the geometry and intensity of geothermal fields, and provides new regional constraints on the cooling history of the footwall and hanging-wall massifs.

\section{Introduction}

Global geothermal energy production is expected to grow rapidly over the next years due to its low environmental impact and increasing technological developments (Van der Zwaan and Della Longa, 2019). Geothermal exploration reveals great potential in different geological contexts (Lund et al., 2011; Dobson, 2016) for several years (Barbier, 2002), which include magmatic environments (e.g. Heffington et al., 1977) and fault systems due to crustal extension (Meixner et al., 2016). Heat advection requires the presence of water such as that commonly found in continental hydrothermal systems (Deming, 1994). This type of system can show temperature and water discharge rates large enough for electricity production in "geothermal doublets", such as those developed in the Basin and Range province (Blackwell et al., 2000; Faulds et al., 2010) or in western Anatolia, Turkey (Roche et al., 2018), with temperatures above $200^{\circ} \mathrm{C}$ (Bertani, 2012). 
Several studies have shown the impact of faults adjacent to topography to control hydrothermal circulation, whereby the hot water flow is enhanced by forced convection (e.g. Forster and Smith, 1989; McKenna and Blackwell, 2004; Taillefer et al., 2017; Sutherland et al., 2017; Volpi et al., 2017; Jordan et al., 2018; Wanner et al., 2019). Even in a poorly active tectonic context, a high topographic gradient and the fracture permeability inherent to normal faults provide good conditions to allow efficient hydrothermal flow, as shown by multiple hot springs located along faults (Taillefer et al., 2017, 2018; Wanner et al., 2019). In this case, meteoric fluids infiltrate from high reliefs in the footwall, heat up at depth, and rise in areas of high permeability along the faults (Grasby and Hutcheon, 2001; Craw et al., 2013). Thus, the circulation of hydrothermal fluids is essentially controlled by topography, the permeability of the host rocks, the geometry of the fault zone (Caine and Tomusiak, 2003; Bense et al., 2013), fracture mineralization (Eichhubl et al., 2009; Griffiths et al., 2016), and the tectonic background of the area (Faulds and Hinz, 2015).

In places where no heat flow data are available (no boreholes), geothermal exploration mainly relies on surface manifestations of hot hydrothermal fluids (such as hot springs, tuff deposits, or recent hydrothermal mineralizations). It has recently been proposed that low-temperature (LT) thermochronology can be used as a low-cost tool to support or extend the exploration of such geothermal systems (Gorynski et al., 2014; Milesi et al., 2019). In the past decades an increasing number of studies revealed the influence of hydrothermal circulations on LT thermochronometers, rendering their interpretation difficult in terms of exhumation history along faults (e.g. Whipp and Ehlers, 2007; Wölfler et al., 2010; Gorynski et al., 2014; Danišík et al., 2015; Valla et al., 2016; Janots et al., 2019; Louis et al., 2019). In this study, we propose an extended analysis of the (U-Th)/He system in apatite (AHe) that is sensitive in a temperature range between 40 and $120^{\circ} \mathrm{C}$ (Gautheron et al., 2009; Shuster and Farley, 2009; Ault et al., 2019), combined with rare-earth element (REE) analyses on the same apatite grains. These coupled analyses are used along the Têt normal fault (Pyrenees) to track the effects of surface and blind thermal systems without evidence of active fluid circulations. In a previous study (Milesi et al., 2019), we showed that the analysis of REE mobility in apatite can help to interpret scattering of AHe ages, which in turn emphasizes hydrothermal imprints on this mineral. In this previous study, we focused on an area located in the vicinity of an active hot spring cluster along the dormant Têt fault in the eastern Pyrenees. The present study investigates a $10 \mathrm{~km}$ long segment of the Têt fault in order to test these tools with two new sampling profiles both in areas lacking current surface manifestations of hot hydrothermal fluids and near the hottest springs along the fault.

\section{Geological setting}

\subsection{Cenozoic Têt fault activity and related exhumation of the eastern Pyrenees}

The Pyrenees form a mountain range $1000 \mathrm{~km}$ long and $150 \mathrm{~km}$ wide at the boundary between the Eurasian and Iberian plates (Fig. 1a). The maximum of shortening occurred during the Eocene in the axial part of the Pyrenees (Vergés et al., 1995; Gibson et al., 2007; Sinclair et al., 2005; Metcalf et al., 2009; Whitchurch et al., 2011; Fillon and van der Beek, 2012) and between the Eocene and early Oligocene in the eastern part (Burbank et al., 1992). This period was characterized by the emplacement of south-verging nappes rooted in the northern part of the range (Vergés et al., 1995; Sibuet et al., 2004; Teixell et al., 2016). In the early Eocene, the balanced cross sections of Ternois et al. (2019) suggest the Eocene thrusting of the Aston-Mont-Louis unit onto the Canigou massif, in agreement with thermochronological data (Maurel et al., 2008). At the end of Oligocene, faults with a NE-SW trend such as the Têt and Tech faults were (re-)activated with normal motion in response to the rifting of the Gulf of Lion (Séranne et al., 1995). Later, two minor tectonic events were recorded on these faults: a Miocene dextral strike-slip phase along the Têt fault led to the formation of pull-apart basins (Fig. 1b) such as the Cerdagne and Roussillon basins (Cabrera et al., 1988; Gibert et al., 2007) and a second extensional tectonic event during the Plio-Quaternary (Carozza and Baize, 2004; Lacan and Ortuño, 2012; Petit and Mouthereau, 2012; Clauzon et al., 2015).

The Têt fault (eastern Pyrenees) reaches $100 \mathrm{~km}$ in length across Palaeozoic rocks from the axial zone, and that separates two domains with different long-time thermal evolution and exhumation history (Fig. 1b). Previous studies at the scale of the eastern Pyrenees using various thermochronometers, such as muscovite and biotite ${ }^{40} \mathrm{Ar} /{ }^{39} \mathrm{Ar}$, zircon fission track (ZFT), (U-Th)/He on zircon (ZHe), apatite fission track (AFT), and (U-Th)/He on apatite (AHe), provide important age constraints on the regional thermal history of the eastern Pyrenees (Maurel et al., 2008; Gunnell et al., 2009; Vacherat et al., 2014, 2016; Milesi et al., 2019; Ternois et al., 2019).

In the hanging wall of the normal Têt fault (north of the fault), ${ }^{40} \mathrm{Ar} /{ }^{39} \mathrm{Ar}$ ages of hornblende $(300.3 \pm 3.1 \mathrm{Ma})$ and biotite $(291.2 \pm 2.8 \mathrm{Ma})$ from the granitic Mont-Louis massif (Fig. 1c) record only the Variscan cooling history (Maurel et al., 2008). By contrast, K-feldspar displays a discordant age spectrum from about 50 to $295 \mathrm{Ma}$ which was interpreted through multiple diffusion domain (MDD) modelling to record the exhumation and cooling effects related to the Pyrenean compressive tectonics in the Eocene. This is consistent with fission tracks and zircon (U-Th)/He ages in the whole massif. AHe data yielded a large age range between $29.7 \pm 1.5$ and $48.7 \pm 2.4 \mathrm{Ma}$ that is indicative of a long residence in the partial retention zone from the middle Eocene 


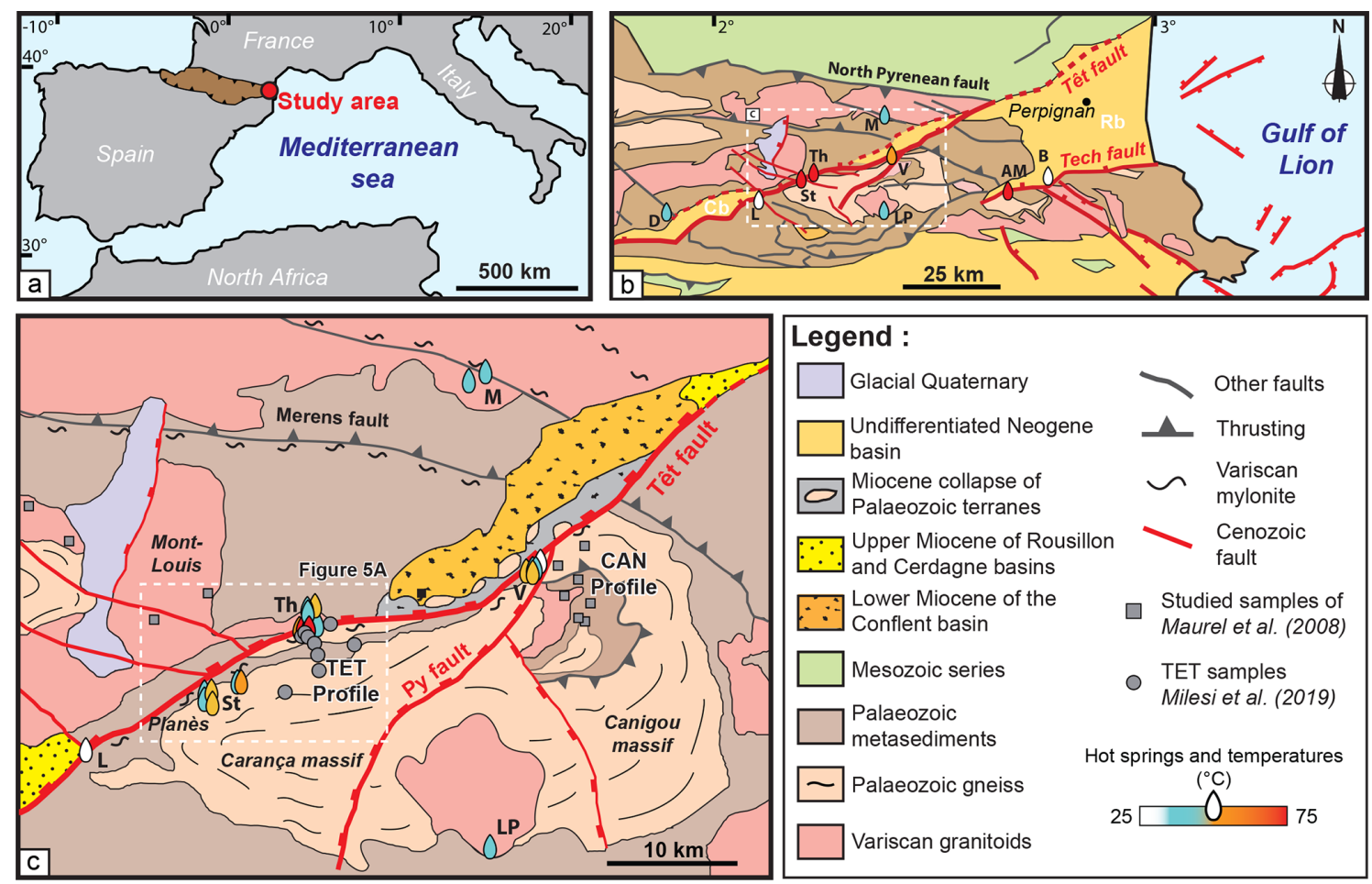

Figure 1. (a) Regional map at the scale of the Mediterranean basin: the outline of the Pyrenees is shown in brown and the study area is indicated with a red dot. (b) Structural map with principal faults and units; hot spring clusters are reported with coloured drops. D: Dorres, L: Llo, St: St Thomas, Th: Thuès-les-bains, V: Vernet-les-bains, LP: La Preste-les-bains, AM: Amélie-les-bains, B: Le Boulou, M: Molitgles-bains. Roussillon basin: Rb, Cerdagne basin: Cb (modified from Taillefer et al., 2017). (c) Local map with the location of previously published AHe ages and the location of the studied area (dashed rectangle, Fig. 5a). Hot springs are also represented by drops (modified from Maurel et al., 2008).

to the lower Oligocene (Maurel et al., 2008; Gunnell et al., 2009).

In the footwall of the Têt fault, samples from the Canigou massif display younger and discordant muscovite and biotite ${ }^{40} \mathrm{Ar} /{ }^{39} \mathrm{Ar}$ ages that range from about $88.3 \pm 16.8$ to $303.9 \pm$ $2.4 \mathrm{Ma}$ for muscovite and from $47.0 \pm 5.9$ to $185.3 \pm 1.7 \mathrm{Ma}$ for biotite. These discordant ages were interpreted to record a thermal overprint on the Variscan basement rocks contemporary to the thinning and associated metamorphism of the North Pyrenean zone (Maurel et al., 2008) and/or the thermal effects associated with the widespread hydrothermal activity that affected the eastern Pyrenees in the Cretaceous (Boulvais et al., 2007; Poujol et al., 2010; Fallourd et al., 2014; Boutin et al., 2016). However, it is likely that the Eocene overthrusting of the northern units (Ternois et al., 2019) played a significant role in this age scattering. Nevertheless, the Canigou massif could have occupied a $\sim 4 \mathrm{~km}$ deeper position with respect to the Mont-Louis massif (Maurel et al., 2008) before its Oligo-Miocene exhumation. Thermal modelling using low-temperature thermochronometers revealed that the Canigou massif was rapidly cooled $\sim 20^{\circ} \mathrm{C} \mathrm{Ma}^{-1}$ between 30 and $25 \mathrm{Ma}$ (Fig. 2) in relation to the Têt fault normal activity (Maurel et al., 2008; Milesi et al., 2019). The
Cenozoic exhumation of the Carança and Canigou massifs is estimated at about $2000 \mathrm{~m}$ (Maurel et al., 2008), but the last period of relief edification and Têt fault activity is still debated. The last vertical movements are related to either the Miocene tectonic phase with a maximum of $300 \mathrm{~m}$ of footwall uplift (Cabrera et al., 1988; Mauffret et al., 2001) or to the Plio-Quaternary tectonic phase with up to $500 \mathrm{~m}$ of exhumation (Carozza and Baize, 2004; Lacan and Ortuño, 2012; Clauzon et al., 2015). Petit and Mouthereau (2012) consider any vertical displacement on the Têt fault to have occurred during the Plio-Quaternary. Numerous NWSE faults, inherited from the Hercynian tectonics (Barbey et al., 2001), are described as brittle faults with post-Miocene activity. These faults are well-expressed near the St Thomas hot spring cluster (Fig. 3, Taillefer et al., 2017 and 2018). In the late to middle Neogene, a global regional uplift of $\sim 1.5$ to $2 \mathrm{~km}$ associated with thermal erosion of the subcontinental lithosphere is evidenced on the basis of multidisciplinary (Gunnell et al., 2009) and thermochronological studies (Fitzgerald et al., 1999).

Today, the Têt fault shows no clear evidence of seismic activity (Souriau and Pauchet, 1998), and no vertical movement is recorded by GPS in the eastern Pyrenees (Masson et 

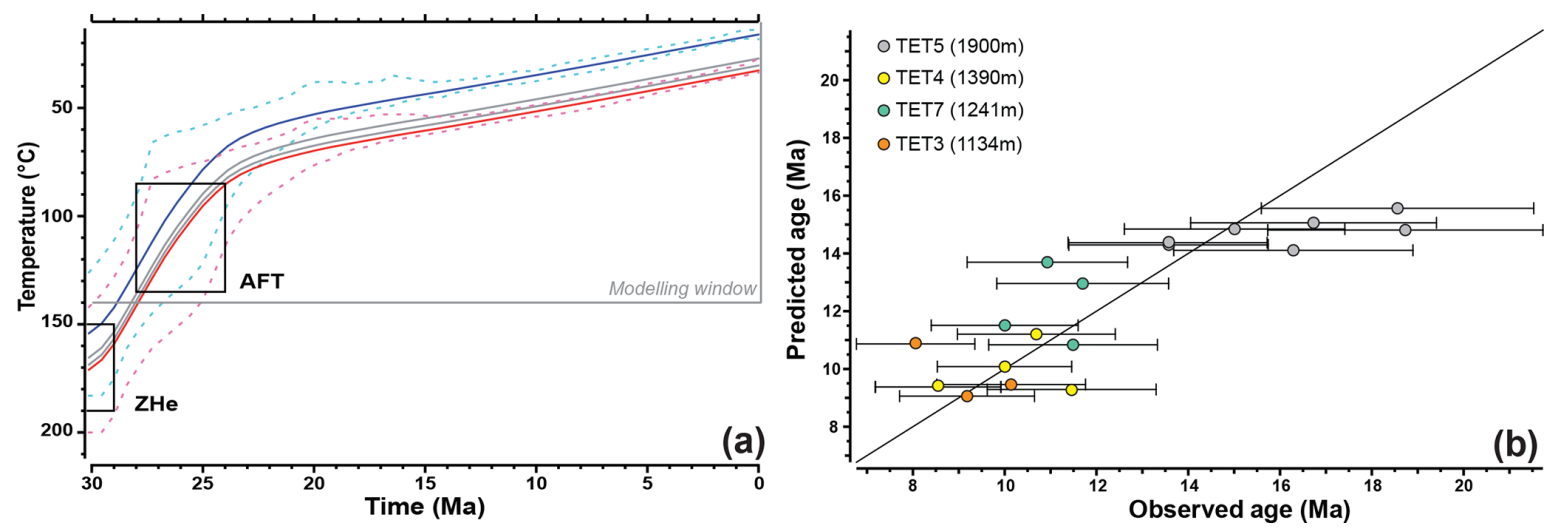

Figure 2. (a) Regional thermal history of the Carança-Canigou range (Têt fault footwall). Thermal modelling was computed with QTQt software (Gallagher, 2012) and Gautheron et al. (2009) diffusion parameters using AHe data from Milesi et al. (2019) and AFT and ZHe data from Maurel et al. (2008). Blue and red T-t paths correspond to the computed thermal history of the most and least elevated samples, respectively. Dashed lines: $95 \%$ confidence interval of T-t paths. (b) Predicted age vs. observed age graph for each apatite grain. The $1: 1$ diagonal line corresponds to an ideal fit of these ages.

al., 2019). Cosmogenic radionuclide data on karst sediments (Sartégou et al., 2018) and on Têt valley fluvial terraces (Delmas et al., 2018) suggest incision rates in the range of 1 and $25 \mathrm{~m}$ per million years since $6 \mathrm{Ma}$.

\subsection{Têt fault damage zone and associated hydrothermal systems}

The Têt fault is characterized by a thick sequence of deformed rocks on both sides of the main fault that can be divided into two distinct zones: the core zone $(\mathrm{CZ})$ and the damage zone (DZ) (Caine et al., 1996; Shipton and Cowie, 2001; Billi et al., 2003; Kim et al., 2004; Berg and Skar, 2005). The $\mathrm{CZ}$ is generally formed by fault rocks composed of breccias, cataclasites, and gouges (e.g. Sibson, 2000; Fossen and Rotevatn, 2016). The CZ of the Têt fault is $10 \mathrm{~m}$ thick and essentially composed of noncohesive breccias supported by clay gouges, cataclasites, and crush breccias formed at the expense of Palaeozoic rocks. Locally the Têt fault displays a multi-core pattern (Thuès-les-Bains, Llo) with small cataclastic fault zones and deformed gneiss lenses within the CZ (see Supplement Sect. S1 for a description of the Thuès-les-Bains $C Z$ ).

The $\mathrm{DZ}$ is a rock volume adjacent to the $\mathrm{CZ}$ characterized by an important number of fractures (Caine et al., 1996; Sibson, 2000; Kim et al., 2004; Agosta et al., 2007; Faulkner et al., 2010). Close to Thuès-les-Bains, on the basis of field measurements of fractures and small faults in the Carança valley, the half-thickness of the DZ is estimated at $400 \mathrm{~m}$ (horizontal distance) with an inner highly fractured DZ of $75 \mathrm{~m}$ (Milesi et al., 2019). The half-thickness of the Têt fault DZ is estimated between 200 and $700 \mathrm{~m}$ using lineament analysis of satellite SPOT images with $5 \mathrm{~m}$ resolution (Taillefer et al., 2017). These values are coherent with fault displacement and damage zone thickness laws assuming a sym- metrical DZ for the fault (Mayolle et al., 2019). In the DZ, fractures are filled with quartz and/or carbonates, and some of them from the inner DZ show chlorite, muscovite, and iron oxides in veins cross-cutting fault rocks.

The Têt valley concentrates 29 hot springs with temperatures between 25 and $75^{\circ} \mathrm{C}$, without seasonal temperature variation and with a relatively homogeneous chemical composition of spring waters (Petit et al., 2014; Supplement Sect. S2). In the studied area, hot springs are distributed in four main clusters. From east to west (Fig. 1b) are Vernet-les-bains (Vernet, $\mathrm{Tw}=36-56^{\circ} \mathrm{C}$ ), Thuès-lesbains (Thuès, $\mathrm{Tw}=35-73^{\circ} \mathrm{C}$ ), St Thomas-Prats-Balaguer (St Thomas, Tw $=38-60^{\circ} \mathrm{C}$ ), and Llo (Tw around $30^{\circ} \mathrm{C}$ ). Stable isotope analyses of hot spring waters indicate a meteoric origin, with an altitude of infiltration above $2000 \mathrm{~m}$ for Thuès and St Thomas, above $1800 \mathrm{~m}$ for Vernet, and between these values for Llo hot springs (Petit et al., 2014). Various geothermometers (silica, chalcedony, $\mathrm{Na} / \mathrm{K}, \mathrm{Na} / \mathrm{Li}$, $\mathrm{Na}-\mathrm{K}-\mathrm{Ca}$ ) show a range of maximum water temperature at depth between 70 and $130^{\circ} \mathrm{C}$, consistent with the surface temperature of emerging water of each cluster (Krimissa, 1992; Taillefer et al., 2018). Hot springs are mainly located in the footwall DZ of the Têt fault except for the Thuès-lesBains area where three hot springs also occur in the hanging wall (Canaveilles, $\mathrm{Tw}=52-60^{\circ} \mathrm{C}$ ). The location of hot springs mainly in the footwall may be related to the occurrence of impermeable metasediments in the hanging wall at the surface (Taillefer et al., 2018) or to the fault CZ, which can act as a barrier of permeability for hydrothermal fluids (e.g. Fisher and Knipe, 1998; Ballas et al., 2012). The local presence of NW-SE faults (e.g. Prats fault near St Thomas) cross-cutting or linked to the Têt fault can also increase permeability and localize channelized fluid upflow.

Figure 4 shows the numerical modelling of fluid circulations along the Têt fault between Thuès-les-Bains and 


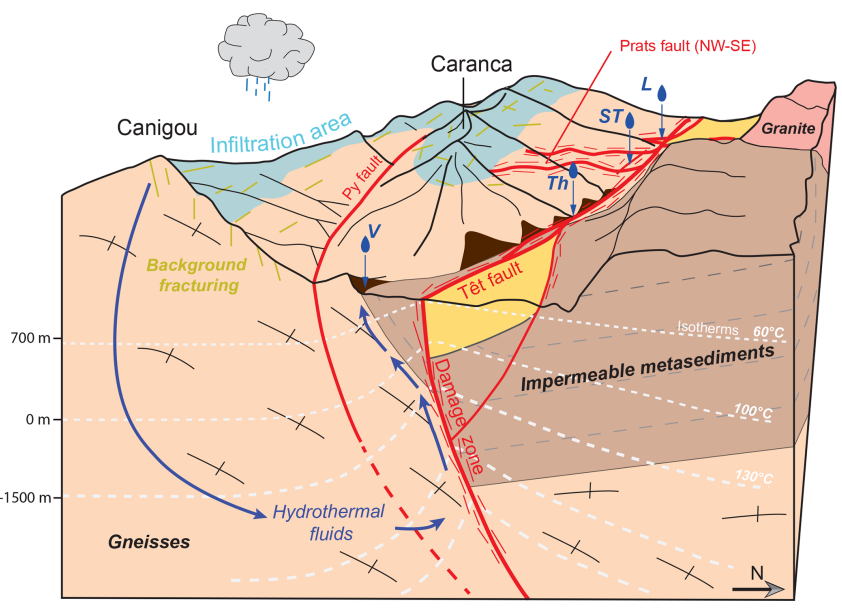

Figure 3. Conceptual model of hydrothermal circulations in the footwall of the dormant Têt fault (hot spring cluster: L: Llo, ST: St Thomas, Th: Thuès-les-bains, V: Vernet-les-bains). Variscan mylonites are in dark brown, and Neogene basins are in yellow (modified after Taillefer et al., 2017).

Planès, which takes into account the combined effects of permeability, topography, and structural discontinuities through field-based geologic and topographic 3D modelling (Taillefer et al., 2018). This model is essentially based on a precise structural map that highlights high-permeability drains and on water chemical analyses that provide constraints on the altitude of fluid infiltration and maximum temperature of water at depth. It shows the presence of a continuous $\sim 7 \mathrm{~km}$ long surface thermal anomaly along the Têt fault only due to the fluid circulation of meteoric water inside the massif. In this model, the simulated geothermal gradient can reach up to $90^{\circ} \mathrm{C} \mathrm{km}^{-1}$ around Thuès-les-Bains, and three main zones of hot surface water temperatures have been identified. Two of them are located at the tips of this anomaly on the hot spring clusters of Thuès-les-Bains and St Thomas. The third enhanced anomaly is located between these two zones, $2 \mathrm{~km}$ west of Thuès-les-Bains at the foot of the Puig Gallinàs massif (2624 m), but lacks actual hot springs. In simulations, hot fluids contributing to these anomalies originate from the infiltration and deep circulation of meteoric water inside the basement and along the fault plane forced by the topographic gradient. Topography appears to be the main parameter to initiate hydrothermal circulations that may have been active since the edification of the relief during the Oligocene (Maurel et al., 2008). By contrast, a negative thermal anomaly is modelled along the fault plane near the Planès plateau (to the west) that is interpreted as a recharge area for hydrothermal fluids that circulate along the Têt fault, supplying the central positive anomaly.

Near Thuès-les-Bains, we recently showed that hydrothermal fluid interactions account for AHe age dispersion (Milesi et al., 2019). Indeed, AHe ages are scattered and rejuvenated or aged in a consistent way with respect to sample position.

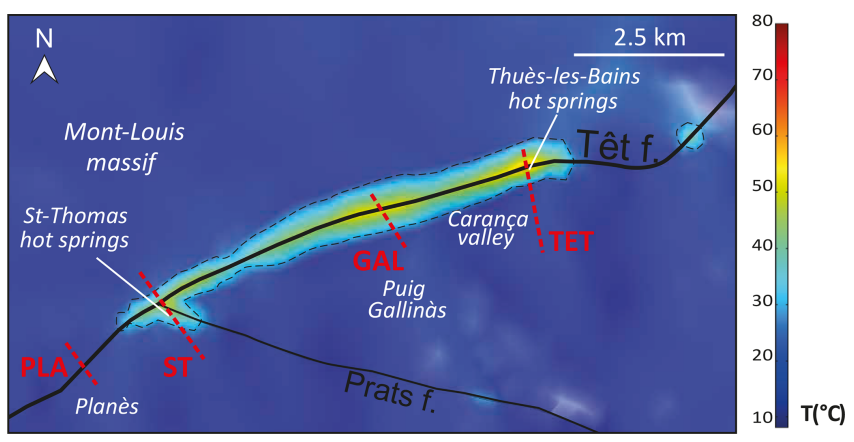

Figure 4. Map view of the modelled surface temperatures taking into account a permeability of $7.10^{-15}$ and $5.10^{-15} \mathrm{~m}^{2}$ for the Têt fault zone and Prats fault zone (black lines), respectively. The dotted black lines correspond to the limit of the modelled surface temperature anomaly (modified after Taillefer et al., 2018). The four red dotted lines are sampling profiles (TET, GAL, ST, and PLA).

In the inner $\mathrm{DZ}$ adjacent to the $\mathrm{CZ}$, where fluid flows were concentrated, AHe ages mainly display ageing with a large scatter between $2.7 \pm 0.3$ and $41.2 \pm 1.9 \mathrm{Ma}$. Samples from the outer DZ mainly show apatite rejuvenation with less scattered ages between $0.9 \pm 0.1$ and $21.1 \pm 1.1 \mathrm{Ma}$. Moreover, we showed that the rejuvenation of apatites in the DZ correlates with a decrease in their REE contents, while their ageing is associated with enriched REE contents compared to samples taken outside the DZ (Milesi et al., 2019).

The thermochronological study presented here extends the study area along the Têt fault footwall to the west up to the potential Planès recharge zone. This enables us to (i) explore the location of the recent thermal anomalies with LT thermochronology coupled with REE analyses along the fault in a way different from numerical modelling and (ii) confirm our previous results on the TET profile. We also incorporated samples from the hanging wall for comparison.

\section{Methodology}

\subsection{Sampling}

A total of 23 new samples of Palaeozoic gneisses, Variscan mylonites, and granites were collected both in the footwall and hanging wall of the Têt fault (Fig. 5), providing 99 single-grain AHe ages and 63 REE analyses. To study the distribution of the thermal anomaly along the Têt fault, sampling was realized roughly perpendicular to the fault: (1) in the vicinity of the Thuès-les-bains (TET profile) and St Thomas (ST profile) hot spring clusters, (2) in areas without hot springs between St Thomas and Thuès-les-bains, i.e. the Carança valley (CAR), at the foot of the Puig Gallinàs (GAL profile) and further west, in the Planès area (PLA), a topographic high along the fault considered to be a recharge zone. The aim of this sampling was to track the effects of recent hydrothermal circulations, mainly in the footwall, adjacent to 
the fault on the behaviour of AHe ages and REE in areas with and without active hot fluid circulations. Our final goal is to provide a first-order map of recent thermal anomalies along the Têt fault and to compare it with that deduced from numerical modelling (Fig. 4). For all the samples, we selected the freshest rocks, up to the highly fractured inner DZ, in order to get the most suitable apatite grains for AHe dating. Figure 6 shows that the alteration and fluid circulation in the DZ are localized along fractures, are very heterogeneous at the scale of the rock sample, and generally weather limited volumes of poorly permeable rocks around fractures (e.g. McCay et al., 2019).

\subsubsection{Sampling near active hot spring clusters: TET and ST profiles}

The TET profile is located in the vicinity of the Thuèsles-Bains cluster, showing the hottest water temperatures (Fig. 5). This profile has already been studied (Milesi et al., 2019), and we completed the sampling of this profile with two samples from the footwall inner DZ (TET1 and TET8) and with one from the hanging wall at the transition between the inner and outer DZ (TETHW). Samples TET1 and TET8 were taken within hydrothermalized, chloritized, and fractured gneisses within the hot spring cluster and $500 \mathrm{~m}$ to the east, respectively. Sample TETHW is a well-preserved, nonfractured augen gneiss collected at a distance of $100 \mathrm{~m}$ from the Têt fault to evaluate the influence of potential hydrothermal activity in this block. The distance from the Têt fault is a horizontal distance throughout the paper.

ST samples are located on a $\sim 3500 \mathrm{~m}$ long profile crossing the St Thomas hot spring cluster. The hot springs at St Thomas are located in the vicinity of a NW-SE fault network connected to the Têt fault (Fig. 3; Taillefer et al., 2017). The dimension of the DZ in St Thomas with a width of $700 \mathrm{~m}$ is larger than in Thuès-les-Bains due to the presence of this fault network. We collected six samples in the footwall along this profile including gneisses, granites, and mylonites (Fig. 6a-c), with elevations between $1107 \mathrm{~m}$ (ST16) and $1480 \mathrm{~m}$ (ST8). Samples in the footwall have an elevation between $1107 \mathrm{~m}$ (ST16) and $1480 \mathrm{~m}$ (ST8). In the DZ, samples ST15 and ST16 are highly fractured mylonites collected close to the fault at 15 and $100 \mathrm{~m}$ (inner DZ), with evidence of chlorite and silica precipitation (Fig. 6g-i). Samples ST2 and ST3 are located around the St Thomas hot springs $(<100 \mathrm{~m})$ in the outer DZ at 250 and $400 \mathrm{~m}$ of distance from the Têt fault, respectively. Sample ST2 is a fractured and chloritized gneiss showing some traces of oxidation, while gneiss ST3 does not display any fracturation or alteration. Outside the footwall DZ, samples ST4 and ST8 were collected at a distance of 835 and $1750 \mathrm{~m}$ from the Têt fault. They look fresh and do not display any evidence of hydrothermal alteration or fractures. In the hanging wall, samples ST1, ST11, ST12, and ST14 were respectively collected at 5, 160, 1900, and $175 \mathrm{~m}$ from the Têt fault and correspond to an altitude variation of $500 \mathrm{~m}$. Sample ST1 is a highly fractured gneiss from the inner DZ and shows an important density of silica veins. In the outer DZ, sample ST14 is a gneiss showing few fractures filled by chlorite, and sample ST11 is an unaltered and non-fractured granite (Fig. 6b). ST12 corresponds to a well-preserved and undeformed outcrop of the Mont-Louis granite.

\subsubsection{Areas with no hot springs: GAL and PLA profiles, CAR valley}

The GAL profile has been sampled in an area devoid of actual hot springs, perpendicularly to the thermal anomaly modelled by Taillefer et al. (2018), approximately midway between the TET and ST profiles (Fig. 4). The samples GAL3, GAL6, and GAL7 are fine-grained gneisses located on a steep slope of the Têt fault footwall at respective distances of 920,330 , and $200 \mathrm{~m}$ from the fault, with an elevation ranging between 1323 and $1065 \mathrm{~m}$. GAL3 is a well-preserved fine-grained gneiss outside the DZ of the Têt fault. In the outer DZ, samples GAL6 and GAL7 have the same lithology as GAL3 but show many quartz- and calcite-filled fractures and locally the occurrence of chlorite and iron oxides. Samples GAL1, GAL2, and GAL8 are gneisses from the hanging wall at a distance of 425, 115, and $40 \mathrm{~m}$ from the Têt fault (Fig. 5). Samples GAL1 and GAL2 from the outer DZ are weakly fractured, whereas sample GAL8 from the inner DZ is highly fractured and highly chloritized and silicified.

We also collected samples from the footwall, $1.5 \mathrm{~km}$ to the west of the Thuès hot spring cluster in the bottom of the Carança valley bottom (Fig. 5), but only one sample (CAR7) from the outer DZ at $200 \mathrm{~m}$ south of the the Têt fault core yields apatites suitable for $(\mathrm{U}-\mathrm{Th}) / \mathrm{He}$ dating. It is a Variscan mylonite that exhibits a well-preserved fine-grained assemblage with little evidence of alteration (scarce growth of sericite after feldspar and of chlorite after biotite) and the presence of quartz-calcite-filled fractures at the outcrop scale (Fig. 6d, e).

On the PLA profile, the samples were located on a small plateau above $1500 \mathrm{~m}$ of elevation $1.5 \mathrm{~km}$ west of the $\mathrm{St}$ Thomas hot spring cluster (Fig. 5). Gneisses PLA2 and PLA5 do not show any evidence of alteration, and sample PLA3 is fractured with the local presence of iron oxides. In the footwall, samples PLA3 and PLA2 are located at a distance of $170 \mathrm{~m}$ (within the outer DZ) and $920 \mathrm{~m}$ (outside DZ) from the principal Têt fault trace and at rather the same elevation (1622 and $1682 \mathrm{~m}$ ). Sample PLA5 is located within the outer DZ of the hanging wall at a distance of $600 \mathrm{~m}$ from the Têt fault. 


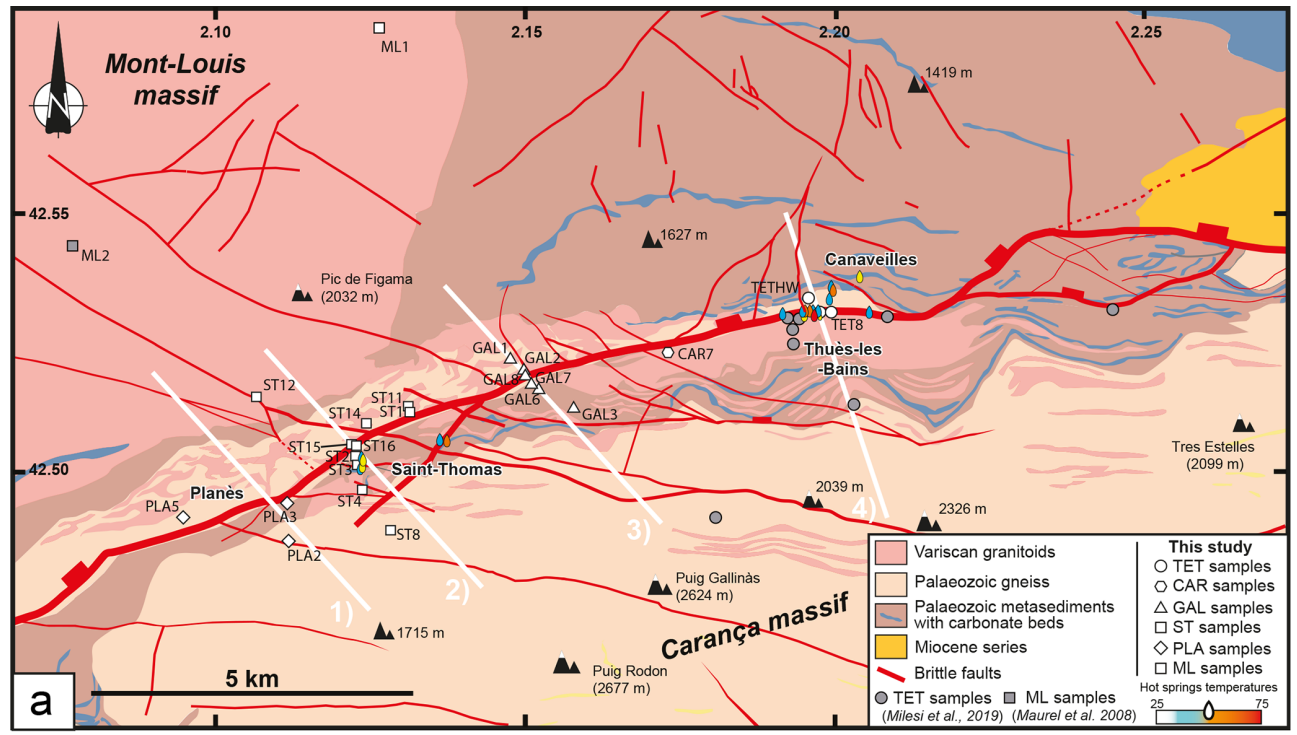

TOPOGRAPHIC CROSS SECTIONS

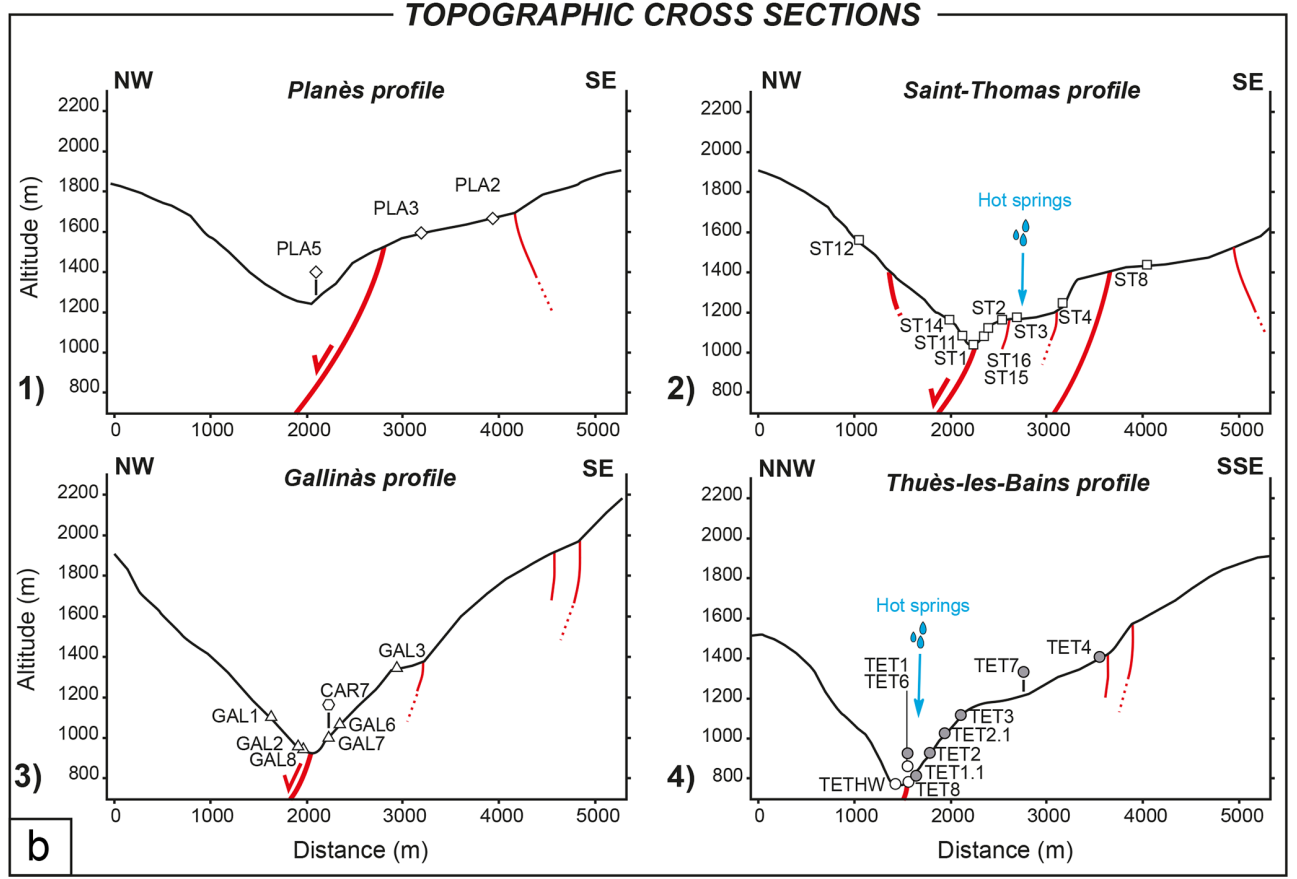

Figure 5. (a) Structural map modified from Taillefer et al. (2017) showing the four sampling profiles. Grey shows samples from previous studies (Maurel et al., 2008; Milesi et al., 2019); in white are new samples from this study. (b) Topographic cross sections of the four transects with the projection of the dated samples (vertical scale exaggerated 2 times). (1) Planès, (2) St Thomas, (3) Gallinàs, and (4) Thuès-les-Bains. White samples are new samples from this study, and grey samples from Thuès-les-Bains are from Milesi et al. (2019). Projected samples are above topographic lines.

\subsection{Analytical method}

\subsection{1 (U-Th)/He analyses}

Apatite (U-Th)/He analyses were conducted in the noble gas laboratory of Géosciences Montpellier. All samples were crushed, and apatite mineral concentrates were gained by heavy liquid methods. Inclusion-free apatite crystals with no evidence of fractures were hand-picked (see Supplement Sect. S3 for apatite grain photos) under a binocular microscope, and grains with an equivalent radius (Rs) above $40 \mu \mathrm{m}$ were selected (see tables in Sect. 4). Each single grain was packed in Pt tubes, placed under vacuum, and heated at $900^{\circ} \mathrm{C}$ for $5 \mathrm{~min}$ with a $1090 \mathrm{~nm}$ fibre laser operating at $20 \mathrm{~W}$. After ${ }^{3} \mathrm{He}$ spiking, gas purification was achieved by a cryogenic trap and two SAES AP-10-N getters, and helium 

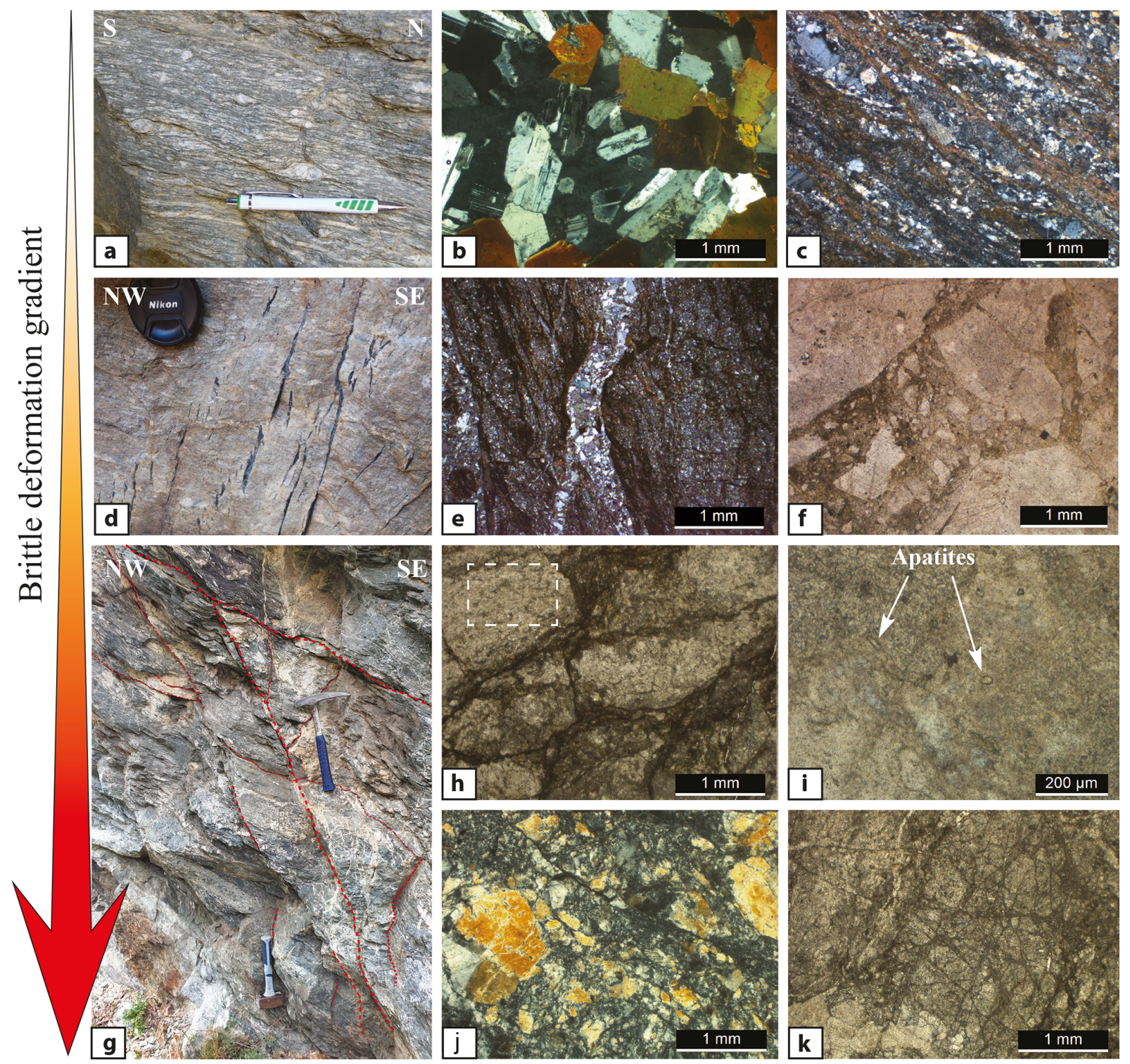

Figure 6. Outcrop and microscopic images of crystalline rocks near the Têt fault (eastern Pyrenees) showing a brittle deformation gradient. Samples outside the damage zone (DZ): (a) typical Canigou augen gneiss; (b) thin section of undeformed Mont-Louis granite, ST12 sample; (c) Variscan mylonite unaffected by fractures. Samples from the outer DZ: (d) silica-filled fractures in mylonites close to CAR7 sample; (e) thin section of previous mylonites with quartz-filled fracture; (f) fracture filled with a micro-breccia near the St Thomas (ST) hot spring cluster. Samples from the inner DZ: (g) intense fracturation in the footwall near the Têt fault on ST profile close to samples ST15 and ST16; (h) thin section of a heterogeneously fractured and altered gneiss (close to sample ST15) showing gneiss lenses less affected by hydrothermal alteration; (i) close view of apatite grains within a gneiss lens (enlargement of dashed rectangle in $\mathbf{h}$ ); (j) thin section of cataclasite next to the Têt fault core; (k) thin section of proto-cataclasite next to the Têt fault core.

content was measured on a quadrupole PrismaPlus QMG 220. The ${ }^{4} \mathrm{He}$ content was determined by the peak height method and is 10-100 times above typical blank levels. A second heating with the same procedure was systematically conducted to check that more than $99 \%$ of ${ }^{4} \mathrm{He}$ was extracted during the first heating. After helium extraction, $\mathrm{Pt}$ tubes were retrieved from the mass spectrometer and put in a $2 \mathrm{~mL}$ polypropylene conical tube. Samples were doubly spiked (230 Th and $233 \mathrm{U}$ ) and dissolved in $100 \mu \mathrm{L}_{5 \mathrm{~N} \mathrm{HNO}}$ $\left(60^{\circ} \mathrm{C}\right.$ for $\left.2.5 \mathrm{~h}\right)$. The resulting solutions were diluted with $900 \mu \mathrm{L} 1 \mathrm{~N} \mathrm{HNO}_{3}$, and $\mathrm{U}(233 \mathrm{U}$ and $238 \mathrm{U})$ and $\mathrm{Th}(230 \mathrm{Th}$ and $232 \mathrm{Th}$ ) were measured by using isotope dilution ICPMS (for more details about the analytical procedure, see $\mathrm{Wu}$ et al., 2016). For age calculation, alpha ejection correction (Farley et al., 1996) was calculated using the Ft software (Gautheron and Tassan-Got, 2010; Ketcham et al., 2011). 
Durango apatite replicates were analysed between four unknown grains and yielded a mean age of $31.31 \pm 1.82$ Ma during the course of this study. This is consistent with the reference age of 31.02 \pm 1.01 Ma given by McDowell et al. (2005).

\subsubsection{REE analyses}

REE and trace element (LILE, HFSE) analyses on single apatite grains were performed at Géosciences Montpellier using the equipment available at the AETE-ISO analytical platform of the OSU OREME (University of Montpellier). Analyses were conducted using the same solutions that were previously used for $\mathrm{U}$ and $\mathrm{Th}$ isotopic analyses following a technique published in earlier reports (e.g. Bruguier et al., 2003). Analyses were performed using an Agilent 7700x quadrupole ICP-MS in the no-gas mode using the pulsecounting mode (three points per peak) and a $50 \mu \mathrm{L} \mathrm{min}-1$ self-aspirating nebulizer. Concentrations were determined by external calibration using multi-element calibration solutions prepared from pure, $10 \mathrm{ppm}$, single-element solutions. $\mathrm{Nb}$ and $\mathrm{Ta}$ were measured by surrogate calibration using $\mathrm{Zr}$ and $\mathrm{Hf}$, respectively, following the method outlined by Jochum et al. (1990) for spark source mass spectrometry. Polyatomic interferences were reduced by optimizing the system to an oxide production level $<1.5 \%$ measured on $\mathrm{Ce}$, and corrections were applied using yields for $\mathrm{MO}+$ and $\mathrm{MOH}+$ determined during the same run by analysing batches of synthetic solutions containing interfering elements (light REE: LREE and Ba) but free of interfered elements (middle REE and heavy REE: HREE). Accuracy was checked by repeated measurements of aliquots of the Durango apatite, which are available in Supplement Sect. S4. The results are consistent with previously published values by Chew et al. (2016); see Supplement Sect. S4 for the REE content table.

\subsubsection{Thermal modelling}

Inverse thermal history modelling was performed with QTQt software (Gallagher, 2012) in order to test whether He thermal diffusion models (Flowers et al., 2009; Gautheron et al., 2009) can reproduce measured AHe ages of a single sample. We have also modelled T-t paths using the new samples collected to complete the thermal history of Milesi et al. (2019) established along the TET profile footwall and to set up a new thermal model for the hanging wall.

\section{Results}

\subsection{Footwall samples}

AHe ages and REE patterns from apatite grains of the footwall of the Têt normal fault are summarized in Table 1 and Figs. 7 and 8. AHe ages obtained in the footwall of the Têt fault range from $0.3 \pm 0.1$ to $21.6 \pm 1.7 \mathrm{Ma}$. No AHe age-eU value relationship is observed (Sect. S5). All analysed apatite grains from samples either outside or inside the DZ show a typical wing-shaped REE pattern with a marked europium anomaly (Fig. 8) characteristic of apatites from S-type granites (Sha and Chappell, 1999; Belousova et al., 2002) that form the protolith of the Canigou augen gneiss (Cocherie et al., 2005; Castiñeiras et al., 2011). For fine-grained gneiss samples of the GAL profile, this anomaly is less pronounced due to an effect of protolith composition (Henrichs et al., 2018). Outside the DZ, apatites of GAL3 have consistently lower REE contents and flatter REE patterns, with a slight negative europium anomaly.

\subsubsection{Near active hot spring clusters: TET and ST profiles}

Along the TET profile, new apatite grains from the previously analysed sample TET1 (Milesi et al., 2019) were dated. This sample is a highly fractured and chloritized gneiss from the inner DZ and within the Thuès-les-Bains hot spring cluster. Two apatite grains yield AHe ages of $0.5 \pm 0.2$ and $0.3 \pm 0.1 \mathrm{Ma}$ and are younger than those previously published on the same sample, i.e. between $4.0 \pm 0.2$ and $41.2 \pm 1.9 \mathrm{Ma}$ (Milesi et al., 2019). Scattering of AHe ages is evident for this sample. However, the eU value $(\mathrm{U}+0.234 \times \mathrm{Th}$; Gastil et al., 1967) of the now analysed grains ranges from 19 to $39 \mathrm{ppm}$ and falls in the range of the previously dated grains. We also dated apatite grains from another gneiss from the inner DZ (TET8) that also shows a very high intra-sample AHe age dispersion from $15.2 \pm 1.2$ to $50.2 \pm 4.0 \mathrm{Ma}$, with rather low eU values between 9 and $27 \mathrm{ppm}$ and variable $\mathrm{Th} / \mathrm{U}$ values between 0.50 and 2.49. It is important to note that the highest $\mathrm{Th} / \mathrm{U}$ ratios are obtained for the oldest apatites (see Sect. S5).

Along the ST profile, apatites from highly fractured Variscan mylonites within the inner DZ (ST15 and ST16) display AHe ages that range from $11.2 \pm 1.1$ to $15.2 \pm 1.2 \mathrm{Ma}$ with low eU values between 8 and $26 \mathrm{ppm}$. However, the moderate intra-sample AHe age dispersion (Table 1) has to be considered with caution because of the low number of analysed grains in each sample (ST15 and ST16; Table 1). The gneiss samples ST2 and ST3 from the outer DZ but close to the St Thomas hot springs show more scattered AHe ages, i.e. between $16.4 \pm 1.5$ and $9.2 \pm 0.5 \mathrm{Ma}$ and between $16.4 \pm 1.3$ and $10.4 \pm 0.8 \mathrm{Ma}$, respectively, and $\mathrm{eU}$ values between 15 and $60 \mathrm{ppm}$. In the ST2 sample, two grains (ST25 and ST2-6, Table 1) with the youngest AHe ages of the sample (12.1 \pm 0.7 and $9.2 \pm 0.6 \mathrm{Ma}$ ) show anomalously high Th contents and high $\mathrm{Th} / \mathrm{U}$ ratios compared to the other grains. This can be indicative of the occurrence of optically undetected tiny Th-rich inclusions within these apatites (see Sect. S5). By contrast with other apatite grains of this study, these Th-rich apatites are enriched in LREE (Fig. 8), consistent with the presence of tiny monazite or allanite inclusions, which are common LREE-rich phases in granites (e.g. Förster, 1998). Therefore, these disturbed REE patterns 

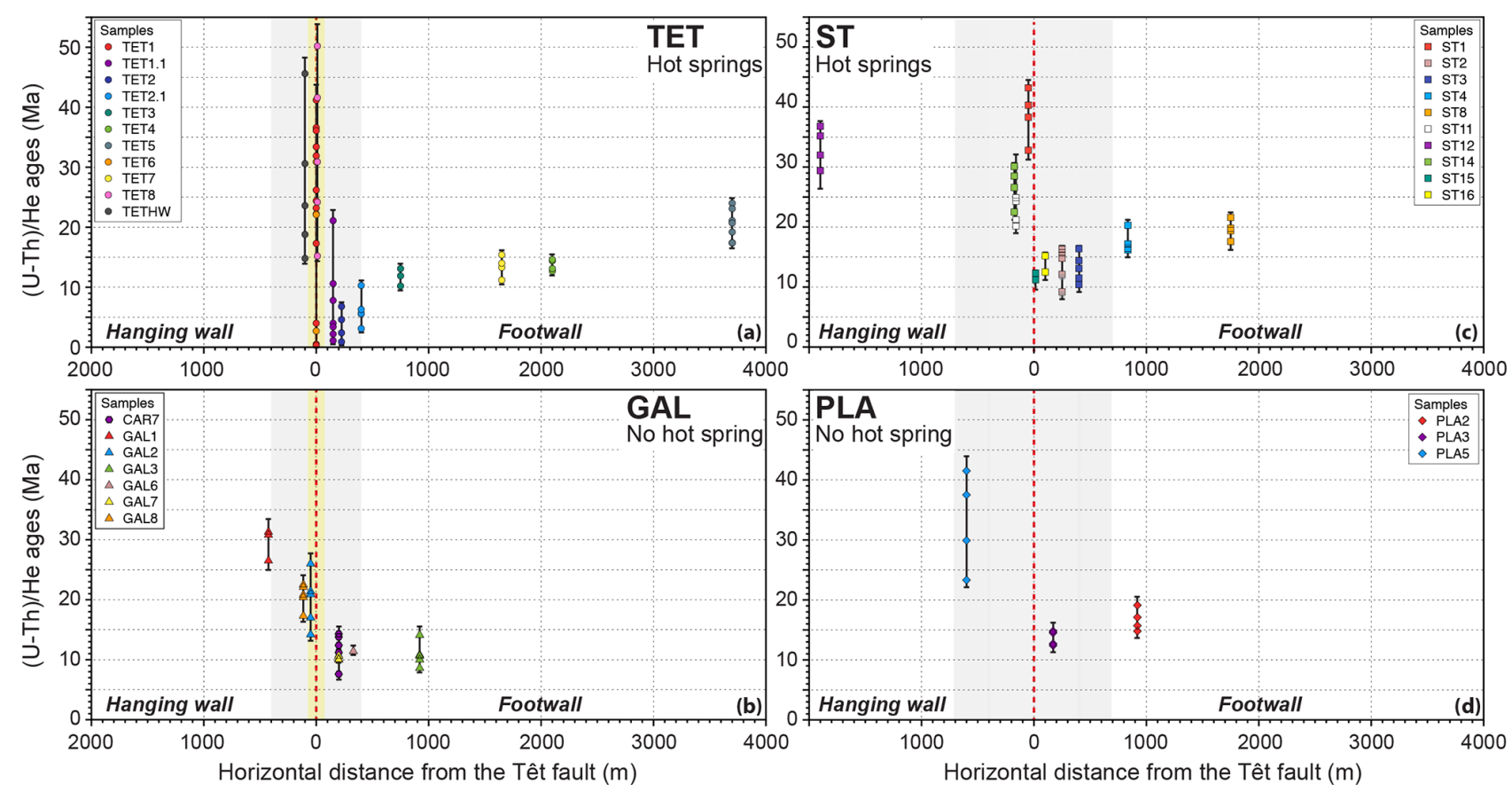

Figure 7. AHe ages as a function of the horizontal distance from the Têt fault. Grey area shows the damage zone of the Têt fault; an inner DZ (yellow) is only distinguished for the TET and GAL profiles according to Milesi et al. (2019).

are not taken into account in the discussion and the corresponding AHe ages are discarded. Outside the footwall DZ, samples ST4 and ST8, at a distance of 835 and $1750 \mathrm{~m}$ from the Têt fault, respectively, show older AHe ages between $16.2 \pm 1.3$ and $21.6 \pm 1.7$ Ma with a limited intra-sample dispersion. The eU values are higher for the leucogranite ST4 (77 to $177 \mathrm{ppm}$ ) than for the gneiss ST8 (29 and $70 \mathrm{ppm}$ ).

\subsubsection{Areas with no hot springs: GAL and PLA profiles, CAR valley}

On the GAL profile, samples GAL3 and GAL7 are fine gneisses from the outside and the outer Têt fault DZ; both show limited AHe age dispersion with ages between $8.6 \pm 0.7$ and $14.1 \pm 1.1 \mathrm{Ma}$. The eU values are higher and more variable in sample GAL7 (17 and $41 \mathrm{ppm}$ ) than in sample GAL3 (10 to $18 \mathrm{ppm})$. A single apatite retrieved from a fractured gneiss (GAL6), next to the sample GAL7, displays an AHe age of $11.4 \pm 0.9 \mathrm{Ma}$ with an eU value of $21 \mathrm{ppm}$. With the exception of one HREE-enriched apatite in sample GAL7, apatite grains from the outer DZ and outside have the same REE patterns (Fig. 8), thus indicating similar geochemical and paragenetic conditions of growth during Variscan Barrovian metamorphism (Hoÿm de Marien et al., 2019).

Sample CAR7 from the outer DZ displays relatively scattered AHe ages, i.e. between $7.6 \pm 0.4$ and $14.3 \pm 0.5 \mathrm{Ma}$, and scattered eU values between 6 and $50 \mathrm{ppm}$. Apatites display consistent REE patterns but variable REE contents (Fig. 8). It is noteworthy that apatites with the lowest REE contents yield younger AHe ages of 7.6 and $10.4 \mathrm{Ma}$ compared to those with higher REE contents with ages between 11.2 \pm 0.5 and $14.3 \pm 0.5 \mathrm{Ma}$ (Fig. 8). A similar tendency was previously observed for apatites sampled in the vicinity of Thuès hot springs and was proposed to be related to combined ${ }^{4} \mathrm{He}$ loss and REE depletion during hydrothermal fluid circulation (TET profile; Milesi et al., 2019).

Further west, on the PLA profile, gneiss sample PLA2 collected outside the DZ shows intra-sample age dispersion between $14.8 \pm 1.2$ and $19.1 \pm 1.5 \mathrm{Ma}$. Sample PLA3, from the outer DZ, displays ages between $12.4 \pm 1.0$ and $14.8 \pm 1.2 \mathrm{Ma}$ that overlap within errors. The eU values vary between 16 and $56 \mathrm{ppm}$ for these samples. Apatites from the outer DZ have lower REE and more variable contents compared to apatites from outside the DZ (Fig. 8). However, no systematic correlation can be observed between AHe ages and REE contents in contrast to the previous sample CAR7.

\subsection{Hanging-wall samples}

AHe ages and REE patterns of apatites from samples of the hanging wall of the Têt normal fault are summarized in Table 2 and Figs. 7 and 9. The first observation is that AHe ages are older than in the footwall, with an age difference of about 15-20 Ma for samples outside the DZ on the ST and GAL profiles. As in the footwall, no AHe age-eU value relationship can be evidenced (Sect. S5). Apatites from the hanging wall display REE patterns basically similar to those of the footwall, suggesting similar protolith compositions. 
Table 1. AHe ages of footwall samples.

\begin{tabular}{|c|c|c|c|c|c|c|c|c|c|c|c|c|c|c|}
\hline Profile & & $\begin{array}{r}\mathrm{Fd} \\
\mathrm{m}\end{array}$ & $\begin{array}{r}\text { Sample/ } \\
\text { grain }\end{array}$ & $\begin{array}{c}\mathrm{Rs} \\
\mu \mathrm{m}\end{array}$ & $\begin{array}{r}\mathrm{U} \\
\mathrm{ppm}\end{array}$ & $\begin{array}{r}\mathrm{Th} \\
\mathrm{ppm}\end{array}$ & $\begin{array}{r}\mathrm{eU} \\
\mathrm{ppm}\end{array}$ & $\mathrm{Th} / \mathrm{U}$ & $\begin{array}{r}{ }^{4} \mathrm{He} \\
\mathrm{ncc} \mathrm{g}{ }^{-1}\end{array}$ & $\begin{array}{r} \pm \mathrm{s} \\
\mathrm{nccg}^{-1}\end{array}$ & $\mathrm{Ft}$ & $\begin{array}{r}\text { Corrected age } \\
\mathrm{Ma}\end{array}$ & $\begin{array}{r}\text { Error } \\
\pm 1 \sigma(\mathrm{Ma})\end{array}$ & $\begin{array}{r}\sum \mathrm{REE} \\
\mathrm{ppm}\end{array}$ \\
\hline & $\mathrm{DZ}$ & 5 & TET1 $(42.5$ & $2819 \mathrm{~N}$ & 2.24912 & E $776 \mathrm{~m})$ & Highly & fracturec & d augen gneis & ss with chlo & & & & \\
\hline \multirow{8}{*}{ profile } & & (5) & TET1-11 & 62.8 & 18.1 & 3.1 & 19 & 0.17 & 860.6 & 43.0 & 0.82 & 0.5 & 0.2 & - \\
\hline & & & TET1-12 & 61.3 & 39.1 & 0.7 & 39 & 0.02 & 1154.8 & 46.2 & 0.80 & 0.3 & 0.1 & - \\
\hline & & 5 & \multicolumn{12}{|c|}{ TET8 $(42.52957 \mathrm{~N} 2.25050 \mathrm{E} 850 \mathrm{~m}$ ) Augen gneiss with chlorite } \\
\hline & & (5) & TET8-1 & 70.8 & 13.4 & 13.7 & 17 & 1.02 & 51869.3 & 1556.1 & 0.84 & 30.9 & 2.5 & - \\
\hline & & & TET8-2 & 58.7 & 20.4 & 27.0 & 27 & 1.32 & 61359.9 & 1840.8 & 0.78 & 24.2 & 1.9 & - \\
\hline & & & TET8-3 & 58.1 & 10.9 & 16.7 & 15 & 1.53 & 58875.8 & 1766.3 & 0.79 & 41.6 & 3.3 & _ \\
\hline & & & TET8-4 & 51.9 & 16.7 & 41.6 & 27 & 2.49 & 126713.5 & 1267.1 & 0.79 & 50.2 & 4.0 & - \\
\hline & & & TET8-5 & 76.8 & 7.9 & 3.9 & 9 & 0.50 & 13892.5 & 694.6 & 0.86 & 15.2 & 1.2 & - \\
\hline CAR & DZ & 200 & \multicolumn{12}{|c|}{ CAR7 $(42.520623 \mathrm{~N} 2.22180 \mathrm{E} 900 \mathrm{~m})$ Fine-grained mylonite with few quartz veins } \\
\hline \multirow[t]{6}{*}{ sample } & & (160) & CAR7-1 & 59.2 & 42.7 & 4.5 & 44 & 0.10 & 46774.3 & 935.48 & 0.79 & 11.2 & 0.5 & 1961.4 \\
\hline & & & CAR7-2 & 78.1 & 5.7 & 1.2 & 6 & 0.22 & 4599.2 & 137.97 & 0.84 & 7.6 & 0.4 & 639.0 \\
\hline & & & CAR7-3 & 79.1 & 11.4 & 1.3 & 12 & 0.11 & 12480.9 & 374.4 & 0.85 & 10.4 & 0.5 & 785.0 \\
\hline & & & CAR7-4 & 70.0 & 23.1 & 3.2 & 24 & 0.14 & 29276.0 & 878.28 & 0.82 & 12.4 & 0.5 & 2040.7 \\
\hline & & & CAR7-5 & 56.5 & 9.8 & 2.4 & 10 & 0.25 & 13434.4 & 403.02 & 0.78 & 13.8 & 0.7 & 1201.1 \\
\hline & & & CAR7-6 & 68.0 & 48.0 & 6.3 & 50 & 0.13 & 70340.1 & 703.4 & 0.82 & 14.3 & 0.5 & 2467.7 \\
\hline \multirow{13}{*}{$\begin{array}{l}\text { GAL } \\
\text { profile }\end{array}$} & DZ & 200 & \multicolumn{12}{|c|}{ GAL7 $(42.51505 \mathrm{~N} 2.19904 \mathrm{E} 1025 \mathrm{~m})$ Fractured fine-grained gneiss with quartz and calcite veins and locally oxides } \\
\hline & & (160) & GAL7-1 & 55.2 & 14.7 & 7.1 & 16 & 0.49 & 16201.3 & 486.03 & 0.77 & 10.6 & 0.3 & 595.4 \\
\hline & & & GAL7-2 & 53.0 & 19.2 & 16.3 & 23 & 0.85 & 21563.9 & 431.26 & 0.77 & 10.0 & 0.4 & 2268.1 \\
\hline & & & GAL7-3 & 56.9 & 33.8 & 11.9 & 37 & 0.35 & 36854.0 & 368.54 & 0.79 & 10.6 & 0.3 & 1671.3 \\
\hline & & & GAL7-4 & 53.5 & 37.6 & 14.3 & 41 & 0.38 & 36945.2 & 369.45 & 0.74 & 10.1 & 0.3 & 2446.8 \\
\hline & & 330 & GAL6 (42. & $51368 \mathrm{~N}$ & 2.19888 & E 10901 & m) Fine- & grained $\mathrm{g}$ & gneiss with fe & ew quartz an & d calcit & veins & & \\
\hline & & (270) & GAL6-1 & 54.4 & 17.0 & 17.0 & 21 & 1.00 & 22342.1 & 446.8 & 0.77 & 11.4 & 0.9 & - \\
\hline & & 920 & GAL3 $(42$. & $51018 \mathrm{~N}$ & 2.20525 & E 13631 & n) Fine- & grained $\mathrm{g}$ & gneiss & & & & & \\
\hline & & (475) & GAL3-1 & 65.9 & 9.9 & 11.5 & 13 & 1.17 & 17196.9 & 343.9 & 0.80 & 14.1 & 1.1 & 1013.4 \\
\hline & & & GAL3-2 & 62.5 & 12.4 & 5.8 & 14 & 0.46 & 14266.4 & 428.0 & 0.79 & 10.8 & 0.9 & 645.7 \\
\hline & & & GAL3-3 & 60.2 & 7.6 & 8.2 & 10 & 1.07 & 7861.2 & 314.4 & 0.79 & 8.6 & 0.7 & 1095.3 \\
\hline & & & GAL3-4 & 72.1 & 9.9 & 8.0 & 12 & 0.81 & 12294.0 & 245.9 & 0.82 & 10.6 & 0.8 & 1067.1 \\
\hline & & & GAL3-5 & 70.8 & 15.7 & 7.7 & 18 & 0.49 & 17324.0 & 519.7 & 0.82 & 10.0 & 0.8 & - \\
\hline & $\mathrm{DZ}$ & 15 & ST15 (42.5 & $0357 \mathrm{~N}$ & 2.16602 & $\mathrm{E} 1123 \mathrm{~m}$ & 1) Highly & y fracture & d mylonite w & vith silica ve & eins & & & \\
\hline profile & & (15) & ST15-1 & 70.8 & 16.7 & 4.5 & 18 & 0.27 & 19703.4 & 985.2 & 0.82 & 11.2 & 1.1 & 1111.9 \\
\hline & & & ST15-2 & 69.5 & 7.8 & 1.6 & 8 & 0.21 & 9959.6 & 597.6 & 0.82 & 12.3 & 1.5 & 786.3 \\
\hline & & 100 & ST16 $(42.5$ & $0331 \mathrm{~N}$ & 2.16692 & $\mathrm{E} 1107 \mathrm{~m}$ & i) Highly & y fracture & d fine-graine & d mylonite & with sil & ca veins & & \\
\hline & & (90) & ST16-1 & 71.5 & 11.2 & 1.7 & 12 & 0.15 & 14439.8 & 433.2 & 0.82 & 12.5 & 1.0 & 962.8 \\
\hline & & & ST16-2 & 59.2 & 22.3 & 3.8 & 23 & 0.17 & 33451.9 & 1003.6 & 0.79 & 15.2 & 1.2 & 1457.9 \\
\hline & & & ST16-3 & 63.2 & 25.7 & 2.9 & 26 & 0.11 & 38790.1 & 775.8 & 0.80 & 15.2 & 1.2 & 1762.1 \\
\hline & & 250 & ST2 $(42.50$ & $150 \mathrm{~N}^{2}$ & $.16661 \mathrm{E}$ & $1217 \mathrm{~m})$ & Chlorit & ized and & locally oxidi & zed gneiss & & & & \\
\hline & & (210) & ST2-1 & 71.5 & 14.4 & 2.1 & 15 & 0.15 & 24260.5 & 1213.0 & 0.82 & 16.4 & 1.5 & 1101.8 \\
\hline & & & ST2-2 & 49.4 & 30.8 & 3.6 & 32 & 0.12 & 41404.3 & 1656.2 & 0.73 & 14.8 & 1.3 & 2235.6 \\
\hline & & & ST2-3 & 65.3 & 41.7 & 17.2 & 46 & 0.41 & 70061.7 & 2101.9 & 0.81 & 15.7 & 1.4 & 9763.8 \\
\hline & & & ST2-4 & 55.6 & 31.2 & 6.0 & 33 & 0.19 & 50171.4 & 2006.9 & 0.78 & 16.3 & 1.5 & 16418.1 \\
\hline & & & ST2-5 & 51.0 & 102.9 & 118.3 & 131 & 1.15 & 142063.2 & 1420.6 & 0.74 & 12.1 & 0.7 & 3960.5 \\
\hline & & & ST2-6 & 66.5 & 27.2 & 72.2 & 45 & 2.65 & 39835.8 & 796.7 & 0.81 & 9.2 & 0.5 & 2544.1 \\
\hline & & 400 & ST3 $(42.50$ & $001 \mathrm{~N} 2$ & $.16697 \mathrm{E}$ & $1174 \mathrm{~m})$ & Unalter & ed gneiss & with biotite & & & & & \\
\hline & & (370) & ST3-1 & 63.9 & 42.9 & 11.9 & 46 & 0.28 & 63845.3 & 1915.4 & 0.80 & 14.4 & 1.2 & - \\
\hline & & & ST3-2 & 74.3 & 15.1 & 2.6 & 16 & 0.17 & 18099.0 & 905.0 & 0.83 & 11.5 & 0.9 & _- \\
\hline & & & ST3-3 & 59.3 & 57.4 & 9.6 & 60 & 0.17 & 89740.7 & 2692.2 & 0.76 & 16.4 & 1.3 & _- \\
\hline & & & ST3-4 & 49.1 & 20.8 & 6.8 & 22 & 0.33 & 20848.7 & 1042.4 & 0.74 & 10.4 & 0.8 & - \\
\hline & & & ST3-5 & 50.1 & 52.9 & 25.5 & 59 & 0.48 & 70579.6 & 2117.4 & 0.76 & 13.1 & 1.0 & - \\
\hline & & 835 & ST4 (42.49 & $567 \mathrm{~N}^{2}$ & 6 & $1249 \mathrm{~m})$ & $\mathrm{Mu}$ & vite 1 & granite & & & & & \\
\hline & & (780) & ST4-1 & 62.5 & 150.6 & 3.6 & 151 & 0.02 & 239669.3 & 2396.7 & 0.79 & 16.5 & 1.4 & 2353.2 \\
\hline & & & ST4-2 & 71.0 & 176.0 & 2.4 & 177 & 0.01 & 303270.8 & 2274.5 & 0.83 & 17.2 & 1.6 & 3700.3 \\
\hline & & & ST4-3 & 61.5 & 138.2 & 2.5 & 139 & 0.02 & 218022.0 & 2180.2 & 0.79 & 16.5 & 1.2 & 2881.9 \\
\hline & & & ST4-4 & 63.5 & 73.6 & 13.1 & 77 & 0.18 & 153280.5 & 1532.8 & 0.82 & 20.3 & 2.1 & 2349.0 \\
\hline & & & ST4-5 & 67.9 & 80.4 & 1.6 & 81 & 0.02 & 132302.5 & 1323.0 & 0.84 & 16.2 & 1.3 & 1758.5 \\
\hline & & 1750 & ST8 $(42.48$ & $856 \mathrm{~N}^{2}$ & $.17261 \mathrm{E}$ & $1480 \mathrm{~m})$ & Augen & gneiss wi & ith biotite & & & & & \\
\hline & & (1630) & ST8-1 & 52.0 & 39.0 & 13.1 & 42 & 0.34 & 83719.3 & 837.2 & 0.76 & 21.6 & 1.7 & 3420.7 \\
\hline & & & ST8-2 & 61.6 & 34.2 & 8.5 & 36 & 0.25 & 70052.1 & 1401.0 & 0.81 & 19.8 & 1.6 & 2708.9 \\
\hline & & & ST8-3 & 57.2 & 27.2 & 8.7 & 29 & 0.32 & 54141.9 & 1082.8 & 0.79 & 19.4 & 1.5 & 2771.4 \\
\hline & & & ST8-4 & 43.5 & 63.2 & 28.4 & 70 & 0.45 & 107043.6 & 1070.4 & 0.72 & 17.6 & 1.4 & 4868.8 \\
\hline PLA & DZ & 170 & PLA3 (42. & $49343 \mathrm{~N}$ & 2.15462 & E $1622 n$ & n) $\mathrm{Fr}_{2}$ & 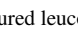 & ocratic & and locally & y oxidiz & & & \\
\hline profile & & (160) & PLA3-1 & 62.0 & 43.6 & 16.6 & 48 & 0.38 & 55098.6 & 551.0 & 0.77 & 12.4 & 1.0 & 1719.5 \\
\hline & & & PLA3-2 & 76.1 & 14.9 & 3.9 & 16 & 0.26 & 20356.2 & 407.1 & 0.84 & 12.7 & 1.0 & 752.2 \\
\hline & & & PLA3-3 & 73.7 & 20.1 & 4.0 & 21 & 0.20 & 31039.5 & 620.8 & 0.82 & 14.8 & 1.2 & 930.3 \\
\hline & & & PLA3-4 & 52.7 & 34.5 & 12.5 & 38 & 0.36 & 49640.8 & 595.7 & 0.76 & 14.5 & 1.2 & 1803.8 \\
\hline & & 920 & PLA2 (42. & $48671 \mathrm{~N}$ & 2.15489 & E $1682 n$ & n) Auge & $\mathrm{n}$ gneiss & & & & & & \\
\hline & & (900) & PLA2-1 & 48.9 & 21.2 & 10.9 & 24 & 0.51 & 36356.6 & 727.1 & 0.74 & 17.1 & 1.4 & 3471.5 \\
\hline & & & PLA2-2 & 52.6 & 11.5 & 6.4 & 13 & 0.55 & 17749.9 & 710.0 & 0.76 & 14.8 & 1.2 & 2417.5 \\
\hline & & & PLA2-3 & 68.4 & 16.4 & 8.3 & 18 & 0.51 & 34659.4 & 519.9 & 0.82 & 19.1 & 1.5 & 2960.8 \\
\hline & & & PLA2-4 & 51.5 & 23.4 & 14.5 & 27 & 0.62 & 38053.9 & 665.9 & 0.75 & 15.7 & 1.3 & 2916.7 \\
\hline
\end{tabular}




\section{Footwall samples}

\section{Samples outside the Têt fault DZ}
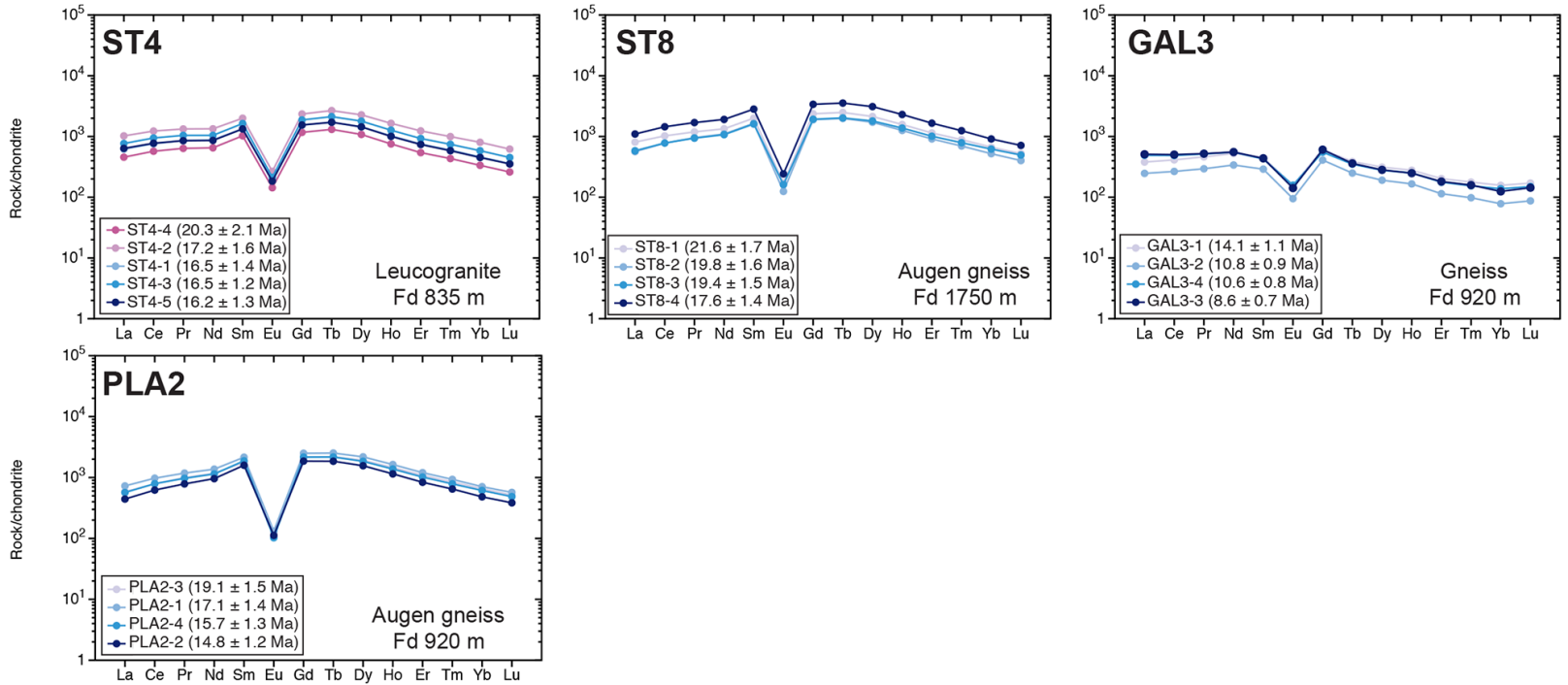

\section{Samples inside the Têt fault DZ}
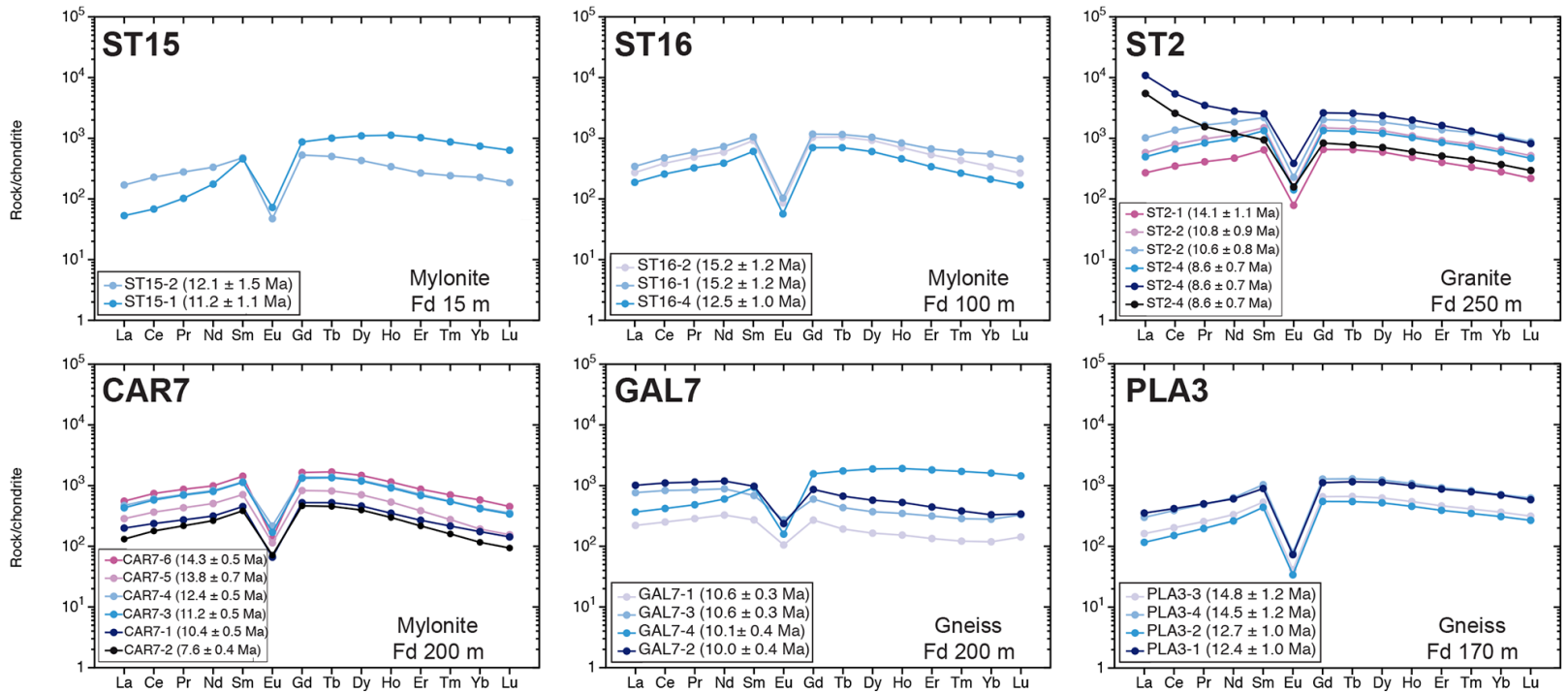

Figure 8. Chondrite-normalized REE patterns (Sun and McDonough, 1989) for the Têt fault footwall samples outside and inside the DZ. Fd: fault distance.

\subsubsection{Near active hot spring clusters: TET and ST profiles}

In the TET profile, AHe ages from sample TETHW, a gneiss lens within the inner DZ, are very dispersed, i.e. between $14.8 \pm 0.7$ and $45.6 \pm 2.7 \mathrm{Ma}$. The eU values are highly dispersed, ranging from 49 to $329 \mathrm{ppm}$, and much higher than those of apatites from the footwall (this work and Milesi et al., 2019). A single grain from sample TETHW (TETHW-5) exhibits significantly lower contents of all REEs compared to other apatites (Fig. 9). It is noticeable that this REE-depleted apatite provides a much younger age $(14.8 \pm 0.7 \mathrm{Ma})$ than other co-existing grains, which is in line with previous results in the footwall of the same profile (Milesi et al., 2019).

In the ST profile, sample ST1 (gneiss) from the inner DZ shows old and scattered AHe ages between $32.8 \pm 2.4$ and $43.2 \pm 3.1 \mathrm{Ma}$. Samples ST11 (gneiss) and ST14 (granite) from the outer DZ display weak intra-sample age dispersion, with ages ranging from $20.2 \pm 1.6$ to $30.1 \pm 2.4 \mathrm{Ma}$. Sample ST12 (granite), from outside the DZ, yields moderately dispersed AHe ages from $29.4 \pm 2.3$ to $36.8 \pm 2.9 \mathrm{Ma}$; eU values of apatite grains appear to be controlled mainly by lithology, between 45 and 86 ppm for gneissic samples (ST1 and ST11) and between 12 and 38 ppm for granitic samples (ST12 and 
ST14). REE patterns of all apatite grains are very similar to each other independently of AHe age variations (Fig. 9).

\subsubsection{Areas with no hot springs: GAL and PLA profiles}

Sample GAL8 from the inner DZ displays dispersed AHe ages between $14.2 \pm 1.1$ and $26.0 \pm 2.1$ Ma with $\mathrm{eU}$ values between 12 and $35 \mathrm{ppm}$. Samples GAL1 (outside the DZ) and GAL2 (outer DZ) from gneisses at a distance of 425 and $115 \mathrm{~m}$ from the Têt fault, respectively, show moderate intrasample AHe age dispersion from $26.5 \pm 2.1$ to $31.3 \pm 2.5 \mathrm{Ma}$ for GAL1 and from $17.3 \pm 1.4$ to $22.5 \pm 1.8$ Ma for GAL2. Sample GAL1 shows low eU values, i.e. between 4 and $9 \mathrm{ppm}$, compared to sample GAL2 with eU values between 24 and $53 \mathrm{ppm}$.

Apatite grains from granite ML1 show intra-sample $\mathrm{AHe}$ age dispersion between $26.2 \pm 2.1$ and $34.1 \pm 2.7 \mathrm{Ma}$. This age range is consistent with an AHe age of $29.8 \pm 1.5 \mathrm{Ma}$ obtained by Maurel et al. (2008) on two apatite populations of 30 grains from the same sample and with the AHe ages of sample ST12 collected at roughly the same elevation in the hanging wall.

A single gneiss sample (PLA5) from the outer DZ shows old and scattered AHe ages between $23.3 \pm 1.9$ and $41.5 \pm$ $3.3 \mathrm{Ma}$ and eU values from 27 to $56 \mathrm{ppm}$ (see Sect. S5 for the AHe vs. eU graph). One apatite grain (PLA5-4) exhibits an REE pattern characterized by a flat LREE section (Fig. 8; Table 1).

\section{Discussion}

\subsection{Footwall of the Têt fault}

In order to interpret AHe ages from the footwall of the Têt fault DZ, we combined these data with those from reference samples outside the DZ. Samples outside the DZ (GAL3, ST4, ST8, and PLA2) show AHe ages with low intra-sample variation (Tables 1 and 2). All apatites from these samples, including those from the work of Milesi et al. (2019), show similar REE patterns, consistent with apatites from S-type granites (Sha and Chappell, 1999), except those from the fine-grained gneiss sample GAL3, which displays an REE pattern usually found in apatites from paragneiss lithologies (Henrichs et al., 2018). We then define two reference REE compositional AHe age fields: one for the GAL profile and another for all other profiles. The eU values for all apatite grains are mostly under $50 \mathrm{ppm}$ with the exception of those from a leucogranite (sample ST4), which is a lithology generally rich in uranium (Cuney, 2010; Ballouard et al., 2017; see Table 2 and Sect. S5). Analysed apatites, however, provide REE patterns similar to those from other gneisses (ST8, PLA2).

\subsubsection{Near active hot spring clusters: TET and ST profiles}

U-Th-He ternary diagrams show a larger intra- and intersample isotopic dispersion for apatites within the DZ compared to those outside the DZ (Fig. 10). This is peculiarly evident for the TET profile wherein newly analysed samples yield perfectly concordant results with previous ones (Milesi et al., 2019). In Fig. 10a, we identify three fields that partially overlap: (1) one defined by apatites outside the DZ (violet dots) with $\mathrm{AHe}$ ages between $\sim 9$ and $25 \mathrm{Ma}$ interpreted to record the regional cooling of the Carança massif (Fig. 2); (2) a second defined by mostly young apatites $(<9 \mathrm{Ma})$ from the outer DZ (red dots) interpreted as apatites with AHe ages partially reset by hydrothermal activity (Milesi et al., 2019); and (3) a third field corresponding to apatites from the inner DZ (green dots) with very scattered AHe ages but mostly above $20 \mathrm{Ma}$. The latter are interpreted as apatites contaminated by excess ${ }^{4} \mathrm{He}$ (Milesi et al., 2019). In Fig. 10b, apatites from the outer and inner DZ along the ST profile (red dots) yield less dispersed AHe ages, but mainly younger, compared to those from outside the DZ (violet dots). Note that apatites retrieved from leucogranite ST4 plot within a distinct compositional field. It is noticeable that along both profiles, a rejuvenation of $\mathrm{AHe}$ ages is observed that is more pronounced along the TET profile.

TET and ST apatites from the DZ display similarly depleted REE, without fractionation between the LREE and HREE patterns, compared to apatites sampled outside the DZ (Fig. 11). This global LREE and HREE depletion is more intense for TET outer-DZ samples compared to ST DZ ones. Note, however, that along the ST profile, the youngest apatites correspond to the most REE-depleted apatites, consistent with the results from the TET profile (Fig. 11). The only three analysed apatite grains from the inner DZ along the TET profile (sample TET1) do not exhibit REE depletion (Milesi et al., 2019). Due to the small number of analyses, the result is not interpreted any further.

Intra- and inter-sample $\mathrm{AHe}$ age dispersion from samples within the DZ cannot be simulated by a common thermal history using existing diffusion models for apatite (Flowers et al., 2009; Gautheron et al., 2009). In particular, the young AHe ages do not fit the regional thermal history defined in Sect. 1 (Sect. S6). In accordance with the results for samples in the outer DZ of the TET profile, they raise questions concerning the origin of the AHe age scattering near the hydrothermal circulation zones (Milesi et al., 2019). We propose that the young apatite grains were subject to hydrothermal alteration that preferentially enhances ${ }^{4} \mathrm{He}$ loss and apatite rejuvenation rather than $\mathrm{U}-\mathrm{Th}$ incorporation. Indeed, as $\mathrm{U}$ and Th have very close solubilities to REEs, it is likely that the behaviour of these elements when apatites interacted with fluids was similar to that of REEs (Cramer and Nesbitt, 1983; Gieré, 1990). Our data show that apatites record REE depletion rather than REE enrichment, which is incon- 
Table 2. AHe ages of hanging-wall samples.

\begin{tabular}{|c|c|c|c|c|c|c|c|c|c|c|c|c|c|c|}
\hline Profile & & $\begin{array}{r}\mathrm{Fd} \\
\mathrm{m}\end{array}$ & $\begin{array}{r}\text { Sample/ } \\
\text { grain }\end{array}$ & $\begin{array}{l}\text { Rs } \\
\mu \mathrm{m}\end{array}$ & $\begin{array}{r}\mathrm{U} \\
\mathrm{ppm}\end{array}$ & $\begin{array}{r}\text { Th } \\
\text { ppm }\end{array}$ & $\begin{array}{r}\mathrm{eU} \\
\mathrm{ppm}\end{array}$ & $\mathrm{Th} / \mathrm{U}$ & $\begin{array}{r}{ }^{4} \mathrm{He} \\
\mathrm{ncc} \mathrm{g}^{-1}\end{array}$ & $\begin{array}{r} \pm \mathrm{s} \\
\mathrm{nccg}^{-1}\end{array}$ & $\mathrm{Ft}$ & $\begin{array}{r}\text { Corrected age } \\
\mathrm{Ma}\end{array}$ & $\begin{array}{r}\text { Error } \\
\pm 1 \sigma(\mathrm{Ma})\end{array}$ & $\begin{array}{r}\sum \mathrm{REE} \\
\mathrm{ppm}\end{array}$ \\
\hline \multirow{6}{*}{$\begin{array}{l}\text { TET } \\
\text { profile }\end{array}$} & $\mathrm{DZ}$ & 100 & \multicolumn{12}{|c|}{ TETHW (42.52972 N 2.24694 E $770 \mathrm{~m})$ Gneiss } \\
\hline & & (100) & TETHW-1 & 52.1 & 324.3 & 18.4 & 329 & 0.06 & 882336.7 & 8823.4 & 0.73 & 30.6 & 1.8 & 5416.1 \\
\hline & & & TETHW-2 & 54.7 & 133.4 & 18.7 & 138 & 0.14 & 298712.7 & 2987.1 & 0.76 & 23.6 & 1.6 & 7926.2 \\
\hline & & & TETHW-3 & 62.6 & 64.4 & 9.0 & 67 & 0.14 & 117207.1 & 2344.1 & 0.78 & 18.8 & 1.1 & - \\
\hline & & & TETHW-4 & 61.8 & 102.1 & 21.6 & 107 & 0.21 & 471710.9 & 4717.1 & 0.80 & 45.6 & 2.7 & 6555.4 \\
\hline & & & TETHW-5 & 49.6 & 47.4 & 5.8 & 49 & 0.12 & 66340.6 & 1990.2 & 0.76 & 14.8 & 0.7 & 1566.4 \\
\hline \multirow{16}{*}{$\begin{array}{l}\text { GAL } \\
\text { profile }\end{array}$} & DZ & 40 & \multicolumn{12}{|c|}{ GAL8 (42.51505 N 2.19904 E $905 \mathrm{~m}$ ) Fine-grained gneiss chloritized and silicified paragneiss } \\
\hline & & (40) & GAL8-1 & 68.9 & 11.2 & 4.2 & 12 & 0.38 & 21079.6 & 421.6 & 0.84 & 17.0 & 1.4 & - \\
\hline & & & GAL8-2 & 57.7 & 32.0 & 13.7 & 35 & 0.43 & 68825.8 & 688.3 & 0.77 & 20.9 & 1.7 & - \\
\hline & & & GAL8-3 & 56.5 & 23.8 & 19.2 & 28 & 0.81 & 68655.2 & 686.6 & 0.77 & 26.0 & 2.1 & - \\
\hline & & & GAL8-4 & 55.1 & 11.8 & 5.8 & 13 & 0.49 & 17437.3 & 523.1 & 0.78 & 14.2 & 1.1 & - \\
\hline & & & GAL8-5 & 58.5 & 15.4 & 14.8 & 19 & 0.96 & 38387.2 & 767.7 & 0.78 & 21.4 & 1.7 & - \\
\hline & & 115 & \multicolumn{12}{|c|}{ GAL2 (42.51707 N 2.19633 E $982 \mathrm{~m}$ ) Fine-grained gneiss } \\
\hline & & (140) & GAL2-1 & 58.0 & 48.9 & 17.5 & 53 & 0.36 & 101612.7 & 1016.1 & 0.78 & 20.4 & 1.6 & - \\
\hline & & & GAL2-2 & 71.7 & 22.4 & 4.6 & 24 & 0.21 & 50982.5 & 611.8 & 0.80 & 22.5 & 1.8 & - \\
\hline & & & GAL2-3 & 64.4 & 21.3 & 19.9 & 26 & 0.93 & 55346.4 & 664.2 & 0.80 & 22.1 & 1.8 & - \\
\hline & & & GAL2-4 & 59.5 & 24.7 & 23.0 & 30 & 0.93 & 49594.0 & 595.1 & 0.79 & 17.3 & 1.4 & - \\
\hline & & & GAL2-5 & 74.0 & 26.6 & 8.0 & 29 & 0.30 & 59317.2 & 889.8 & 0.83 & 20.8 & 1.7 & - \\
\hline & & 25 & \multicolumn{12}{|c|}{ GAL1 $(42.51881 \mathrm{~N} 2.19395$ E $1081 \mathrm{~m})$ Augen gneiss } \\
\hline & & (480) & GAL1-1 & 60.6 & 4.5 & 3.6 & 5 & 0.80 & 15934.3 & 478.0 & 0.79 & 31.3 & 2.5 & - \\
\hline & & & GAL1-2 & 59.9 & 8.1 & 3.9 & 9 & 0.48 & 22677.0 & 453.5 & 0.78 & 26.5 & 2.1 & - \\
\hline & & & GAL1-3 & 60.1 & 3.4 & 4.0 & 4 & 1.17 & 12565.9 & 439.8 & 0.78 & 30.8 & 2.5 & - \\
\hline \multirow{5}{*}{$\begin{array}{l}\text { ML } \\
\text { sample }\end{array}$} & & 5000 & \multicolumn{12}{|c|}{ ML1 $(42.5898083$ N 2.184692 E $1400 \mathrm{~m})$ Granite } \\
\hline & & $(5150)$ & ML1-1 & 60.0 & 31.0 & 39.0 & 40.4 & 1.3 & 120757.3 & 1207.6 & 0.81 & 30.5 & 2.4 & - \\
\hline & & & ML1-2 & 50.9 & 36.0 & 45.0 & 46.9 & 1.3 & 112014.0 & 1120.1 & 0.76 & 26.2 & 2.1 & - \\
\hline & & & ML1-3 & 61.8 & 17.1 & 25.0 & 23.1 & 1.5 & 60151.0 & 962.4 & 0.79 & 27.4 & 2.2 & - \\
\hline & & & ML1-4 & 66.0 & 18.6 & 12.0 & 21.6 & 0.7 & 70099.4 & 1261.8 & 0.79 & 34.1 & 2.7 & - \\
\hline \multirow{21}{*}{$\begin{array}{l}\text { ST } \\
\text { profile }\end{array}$} & $\mathrm{DZ}$ & 5 & \multicolumn{12}{|c|}{ ST1 $(42.50798$ N 2.17611 E $1073 \mathrm{~m})$ Highly fractured leucocratic gneiss with silica veins } \\
\hline & & (5) & ST1-1 & 73.9 & 58.4 & 5.6 & 60 & 0.10 & 235977.6 & 2359.8 & 0.81 & 40.3 & 3.2 & 4134.2 \\
\hline & & & ST1-2 & 63.4 & 70.8 & 3.3 & 72 & 0.05 & 227052.2 & 3405.8 & 0.80 & 32.8 & 2.4 & 3063.4 \\
\hline & & & ST1-3 & 68.4 & 79.1 & 3.1 & 80 & 0.04 & 299652.6 & 2996.5 & 0.81 & 38.3 & 2.7 & 4438.1 \\
\hline & & & ST1-4 & 62.8 & 83.8 & 8.5 & 86 & 0.10 & 358555.4 & 3585.6 & 0.80 & 43.2 & 3.1 & 2632.5 \\
\hline & & 160 & \multicolumn{12}{|c|}{ ST11 (42.51047 N 2.17598 E $1081 \mathrm{~m})$ Unaltered gneiss with biotite } \\
\hline & & (160) & ST11-1 & 60.9 & 63.0 & 19.7 & 68 & 0.31 & 136793.9 & 1504.7 & 0.79 & 21.2 & 1.7 & 5105.5 \\
\hline & & & ST11-2 & 61.9 & 75.8 & 25.7 & 82 & 0.34 & 187572.8 & 1875.7 & 0.78 & 24.3 & 1.9 & 6878.8 \\
\hline & & & ST11-3 & 76.4 & 53.7 & 25.6 & 60 & 0.48 & 120320.0 & 1443.8 & 0.83 & 20.2 & 1.6 & 6005.8 \\
\hline & & & ST11-4 & 55.6 & 42.2 & 13.0 & 45 & 0.31 & 101862.1 & 1018.6 & 0.75 & 24.9 & 2.0 & 4648.1 \\
\hline & & 175 & \multicolumn{12}{|c|}{ ST14 $(42.50748$ N 2.16848 E $1139 \mathrm{~m})$ Granite with biotite and little evidence of chloritization } \\
\hline & & (200) & ST14-1 & 71.4 & 21.9 & 2.5 & 22 & 0.11 & 64392.2 & 965.9 & 0.83 & 28.5 & 2.3 & - \\
\hline & & & ST14-2 & 55.9 & 17.6 & 3.5 & 18 & 0.20 & 38848.5 & 1165.5 & 0.77 & 22.5 & 1.8 & - \\
\hline & & & ST14-3 & 66.3 & 36.7 & 4.4 & 38 & 0.12 & 107444.1 & 1074.4 & 0.78 & 30.1 & 2.4 & - \\
\hline & & & ST14-4 & 59.4 & 32.7 & 10.3 & 35 & 0.31 & 88734.6 & 1064.8 & 0.79 & 26.6 & 2.1 & - \\
\hline & & 1900 & \multicolumn{12}{|c|}{ ST12 (42.51239 N 2.14921 E 1552 m) Granite with biotite } \\
\hline & & $(2200)$ & ST12-1 & 65.2 & 16.7 & 12.2 & 20 & 0.73 & 55653.7 & 1113.1 & 0.80 & 29.4 & 2.3 & 2224.0 \\
\hline & & & ST12-2 & 72.9 & 15.8 & 11.4 & 19 & 0.72 & 63720.2 & 955.8 & 0.81 & 35.2 & 2.8 & 1836.6 \\
\hline & & & ST12-3 & 74.0 & 23.5 & 8.8 & 26 & 0.37 & 73803.2 & 1291.6 & 0.81 & 29.4 & 2.4 & 1651.5 \\
\hline & & & ST12-4 & 57.1 & 10.1 & 6.1 & 12 & 0.60 & 39116.4 & 1564.7 & 0.76 & 36.8 & 2.9 & 1293.8 \\
\hline & & & ST12-5 & 72.6 & 26.1 & 17.4 & 30 & 0.66 & 94696.8 & 1420.5 & 0.81 & 32.0 & 2.6 & 3268.7 \\
\hline PLA & $\mathrm{DZ}$ & 600 & \multicolumn{12}{|c|}{ PLA5 $(42.49059 \mathrm{~N} 2.13607 \mathrm{E} 1560 \mathrm{~m})$ Two mica fine-grained gneiss samples } \\
\hline \multirow[t]{4}{*}{ profile } & & (610) & PLA5-1 & 59.8 & 29.6 & 10.8 & 32 & 0.36 & 72354.2 & 795.9 & 0.80 & 23.3 & 1.9 & 2349.5 \\
\hline & & & PLA5-2 & 69.2 & 26.1 & 15.6 & 30 & 0.60 & 121524.9 & 1215.2 & 0.81 & 41.5 & 3.3 & 2766.9 \\
\hline & & & PLA5-3 & 48.1 & 22.3 & 19.2 & 27 & 0.86 & 74554.5 & 1118.3 & 0.77 & 29.9 & 2.4 & 2560.1 \\
\hline & & & PLA5-4 & 77.3 & 54.8 & 3.6 & 56 & 0.06 & 203870.1 & 2038.7 & 0.81 & 37.5 & 3.0 & 3244.4 \\
\hline
\end{tabular}

Fd: fault horizontal distance, with the fault normal distance between brackets; Ft: alpha ejection correction (Farley et al., 1996). Italic values between brackets are fault normal distances. 
Hanging-wall samples

\section{Sample outside the Têt fault DZ Samples inside the Têt fault DZ}
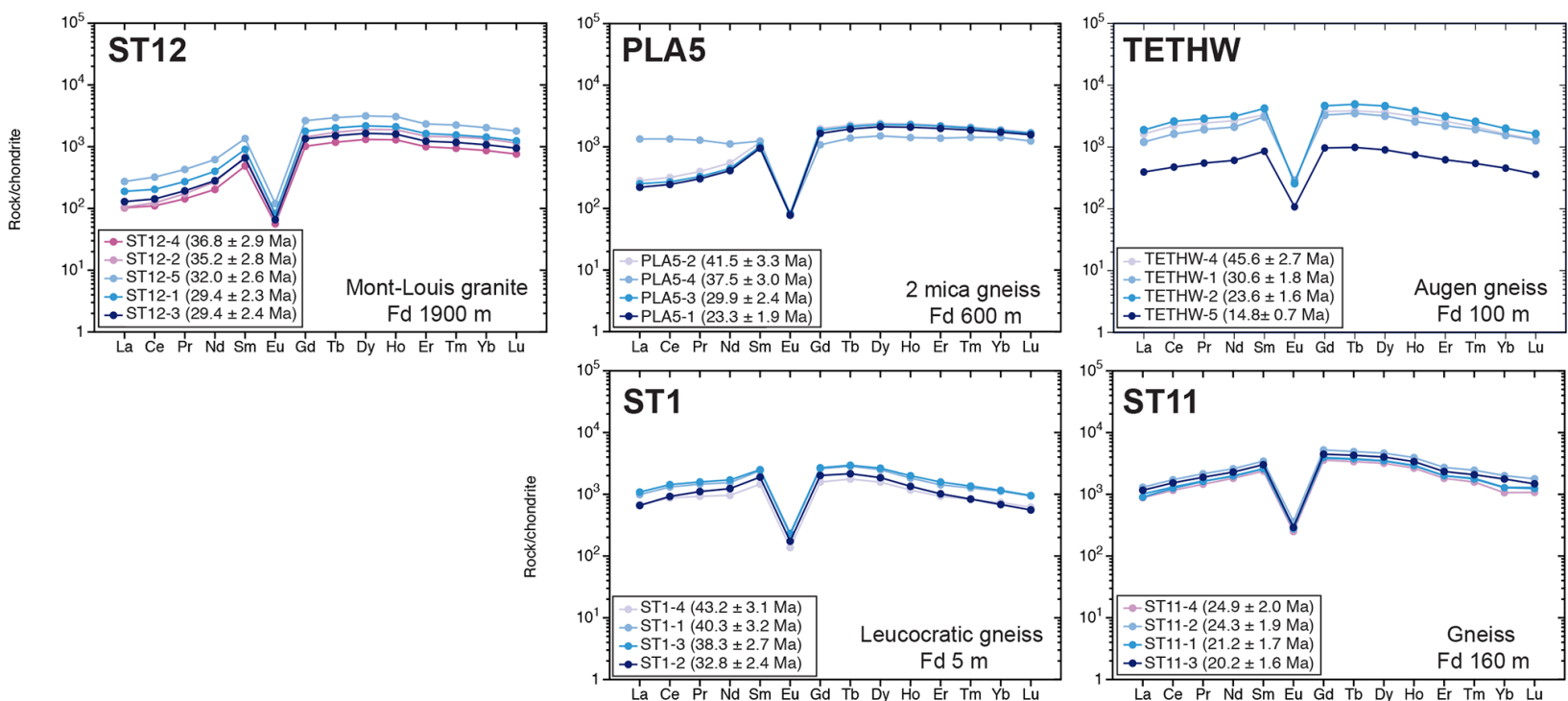

Figure 9. Chondrite-normalized REE patterns (Sun and McDonough, 1989) for the Têt fault hanging-wall samples. REE patterns are reported for samples outside and inside the DZ. Fd: fault distance.
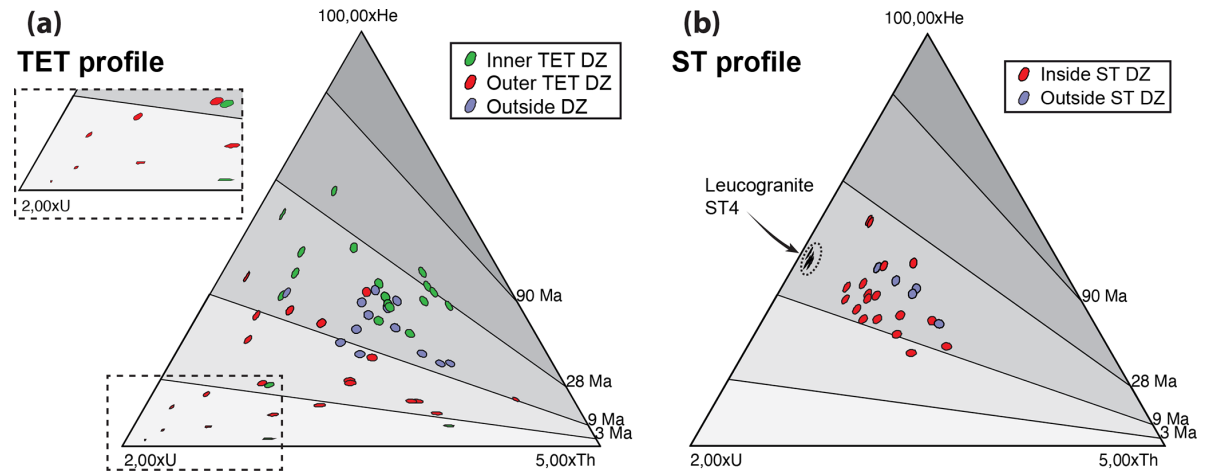

Figure 10. U-Th-He diagrams using Helioplot (Vermeesch, 2010) for (a) TET (this study and Milesi et al., 2019) and (b) ST profile samples (hot spring clusters).

sistent with the incorporation of $\mathrm{U}$ and Th (Figs. 10 and 11; Milesi et al., 2019). REE depletion without fractionation associated with hydrothermal alteration of apatite grains has already been evidenced experimentally (Harlov et al., 2005). These authors showed that the reaction zone region of treated apatite is depleted in $\mathrm{REE}+\mathrm{Y}$ and $\mathrm{Cl}$ compared to the unaffected region and that REEs have been carried away by fluids circulating through nano-channels or nano-voids that developed within the lattice of reacting apatites. As ${ }^{4} \mathrm{He}$ is mainly trapped in lattice defects (Zeitler et al., 2017; Ault et al., 2019), it is highly susceptible to dissolution in fluids and thus to be lost from the host apatite during hydrothermal alteration processes. Indeed, it is well-known that hydrothermal fluids are highly ${ }^{4} \mathrm{He}$ enriched in highly fractured granitic environments, even in the absence of $U$ mineralization (e.g. Andrews and Lee, 1979; Paternoster et al., 2017). Variable REE loss between apatite grains from different samples or even at an intra-sample scale can also be related to the heterogeneity of hydrothermal fluid circulations (Fig. 5, Caine et al., 1996; Bense et al., 2013). Indeed, even at the thin-section scale, unaltered domains can be distinguished from more altered domains, thus reflecting a variable imprint of fluid interaction (Fig. 6h). The chemistry and temperature of the fluid flow may change with time (Favara et al., 2001; Cox et al., 2015); however, it is noticeable that apatite rejuvenation, $\mathrm{AHe}$ age dispersion, and $\mathrm{REE}$ depletion are much more prominent near the Thuès hot springs than near St Thomas (Figs. 10 and 11). This may be related to 

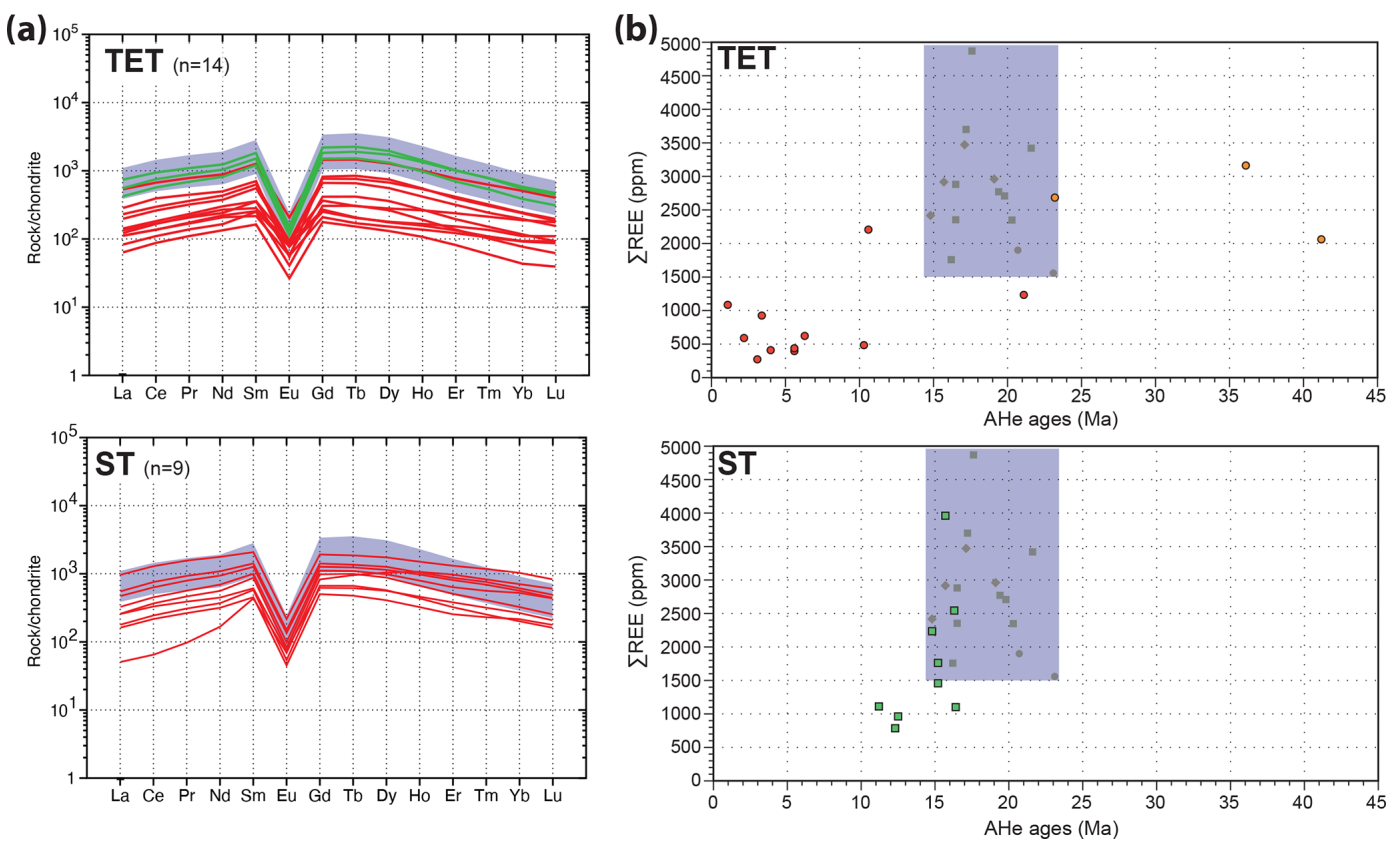

Figure 11. (a) Individual REE patterns of samples within the DZ for the TET and ST profiles; purple field: compositional field of samples outside the DZ defined by 13 REE spectra (gneiss samples TET5, ST4, ST8, and PLA2). For the TET profile, samples from the inner DZ (green) and outer DZ (red) are distinguished. (b) Sum of REE contents as a function of AHe ages. The purple field corresponds to REE contents from samples outside the DZ. The REE depletion is associated with a rejuvenation of AHe ages.

more pronounced hydrothermal fluid circulations near Thuès as exemplified by the larger number of hot springs near Thuès (10 springs) than St Thomas (four springs). The specific topography around the Thuès area (Taillefer et al., 2017) or possible enhanced permeability at depth can favour longerlived hydrothermal and higher fluid temperatures in Thuès (up to $73^{\circ} \mathrm{C}$ vs. $<60^{\circ} \mathrm{C}$ at $\mathrm{St}$ Thomas). We cannot exclude an impact of the intersecting fault network around St Thomas (Fig. 5), which may be responsible for an increase in rock permeability close to the surface as well as flow and heat dispersion into a larger volume of fractured rocks compared to the more channelized system observed within the Thuèsles-Bains hot spring cluster. This is independently supported by the location of the St Thomas and nearby Prats-Balaguer hot springs on secondary NW-SE and NE-SW faults crosscutting or branched onto the Têt fault (Fig. 4), which contrasts with the Thuès hot springs that are all located adjacent to the Têt fault (Fig. 5).

\subsubsection{Areas with no hot springs: GAL and PLA profiles, CAR valley}

Slightly rejuvenated and scattered AHe ages and depleted REE patterns are also observed for apatite grains from outer DZ footwall samples located in two areas away from hot springs clusters: the Carança valley (CAR) and Planès profiles (PLA; Figs. 12a and 13a).

CAR7 apatites from the outer DZ at $\sim 2 \mathrm{~km}$ west of the Thuès hot spring cluster exhibit dispersed and reset AHe ages but are also depleted in REE relative to the outside DZ reference samples (Fig. 13). They are less rejuvenated, but their ages are consistent with AHe ages from the TET outer DZ and their REE depletion is less pronounced (Figs. 10 and 13). Yet again, AHe age dispersion cannot be simulated by a common thermal history regardless of the diffusion model for apatite (Flowers et al., 2009; Gautheron et al., 2009), suggesting opening of the apatite $(\mathrm{U}-\mathrm{Th}) / \mathrm{He}$ system (see Sects. 2.1 and S6).

Consequently, despite the lack of hot springs in the Carança valley, CAR7 apatites appear to record some thermal resetting as in the TET outer DZ. This suggests that hydrothermal circulations took place in the Carança valley but are no longer active. The lack of surface hydrothermal circulation today may be related to the sealing of fluid-filled fractures, in agreement with the occurrence of calcite- and/or silica-filled fractures in this area (Fig. 5d-e; Milesi et al., 2019). A resulting question is whether or not this hydrothermal system can be linked to that of Thuès-les-bains. If so, the data on TET and CAR samples would suggest the presence of an intense and recent hydrothermal flow over a larger segment of the fault than today and thus a larger thermal anomaly around Thuès than that indicated by numerical modelling (Taillefer et al., 2018). In this respect, the end of surface hydrothermal activity in the Carança valley might be very recent, while a blind geothermal system could still exist in the subsurface. 

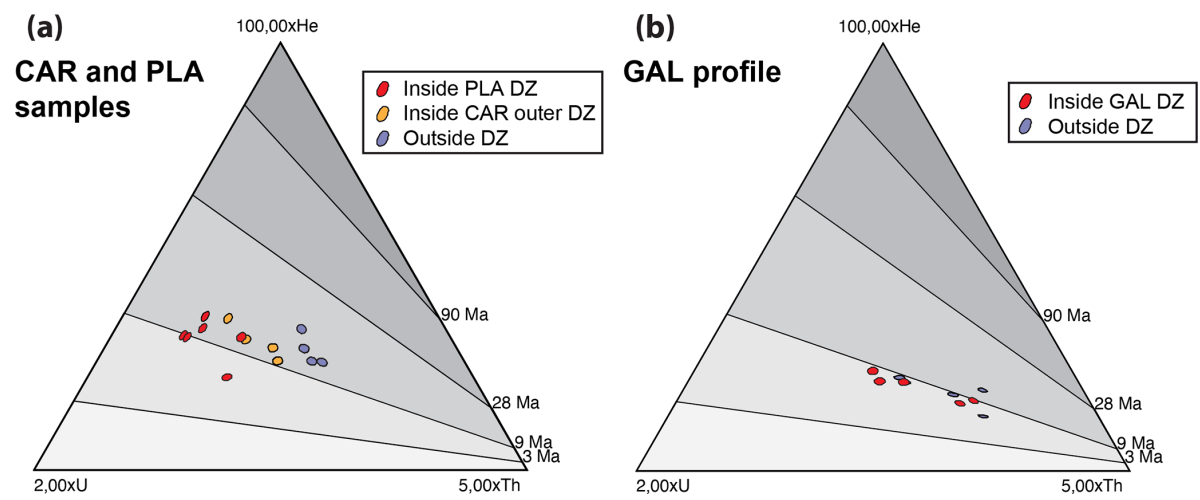

Figure 12. U-Th-He diagrams using Helioplot (Vermeesch, 2010) for (a) CAR and PLA samples (this study and Milesi et al., 2019) as well as (b) GAL profile samples (no hot springs).

(a)
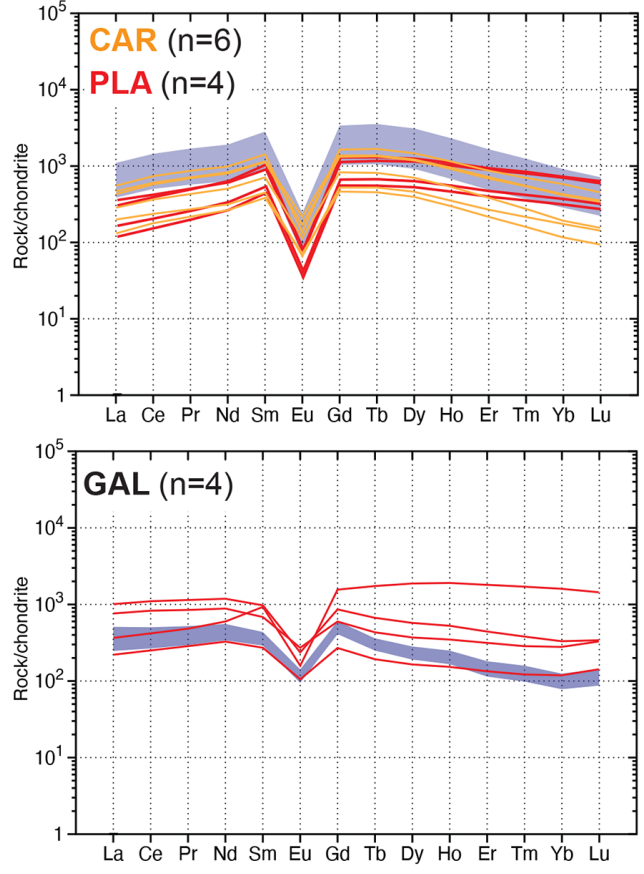

(b)
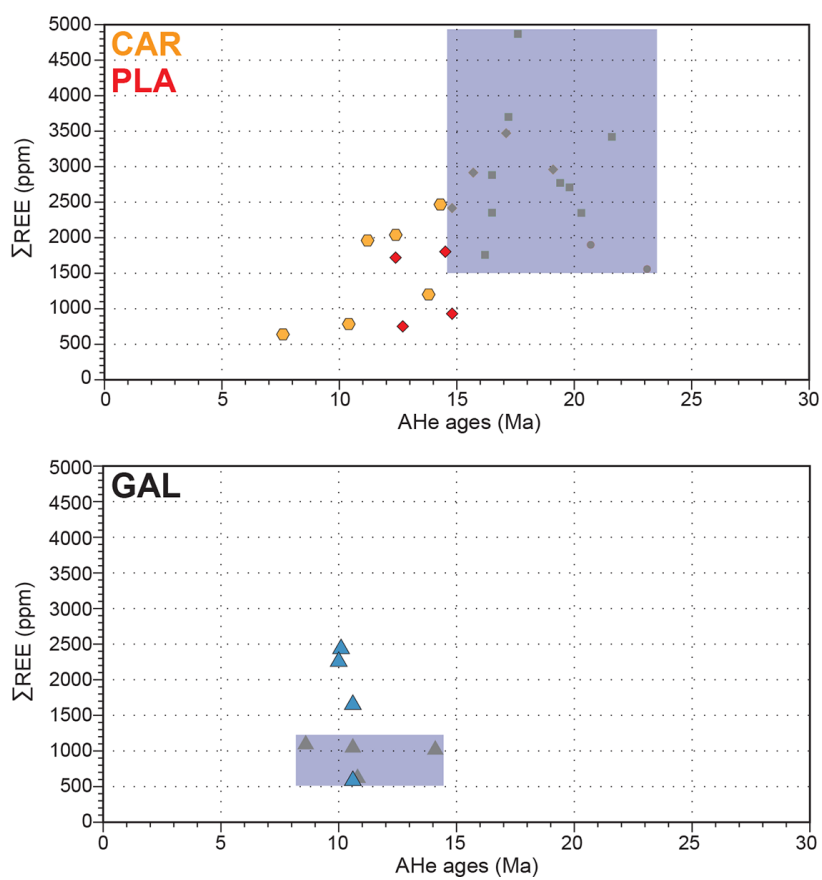

Figure 13. (a) Individual REE patterns of samples within the DZ; in the top part, the purple field is defined by 13 REE spectra (gneiss samples TET5, ST4, ST8, and PLA2) from outside the DZ. In the bottom part, the purple field comes from the four REE analyses from the GAL3 sample (outside the DZ). (b) Sum of REE contents as a function of AHe ages. The purple field corresponds to samples outside the DZ showing consistent REE patterns. The depletion of all REEs in PLA and CAR DZ samples is associated with a rejuvenation of AHe ages.

In the Planès area, which should correspond to a recharge area of the hydrothermal system with cold surface water circulations (Taillefer et al., 2018), apatite grains from sample PLA3 in the outer DZ yield similar results to the ones from the St Thomas hot spring cluster with variously depleted REE patterns and ages between $12.4 \pm 1.0$ and $14.8 \pm 1.2 \mathrm{Ma}$ (Figs. 7 and 13). These young ages at $1600 \mathrm{~m}$ of altitude do not fit the regional thermal history depicted in Fig. 2. The geothermal anomaly around St Thomas might have extended $1.5-2 \mathrm{~km}$ to the west, which is inconsistent with present-day numerical thermal modelling (Taillefer et al., 2018). Alternatively, a more local hydrothermal system may have been active on the plateau independently of that of St Thomas. The Planès area, similarly to the Carança valley, may also correspond to a blind geothermal system or a palaeo-system. Both locations might then represent potential sites for future geothermal exploration.

At the foot of the Puig Gallinàs massif (GAL profile), our results do not evidence significant $\mathrm{AHe}$ age scattering, while REE content is more variable within the outer DZ (Fig. 13). 


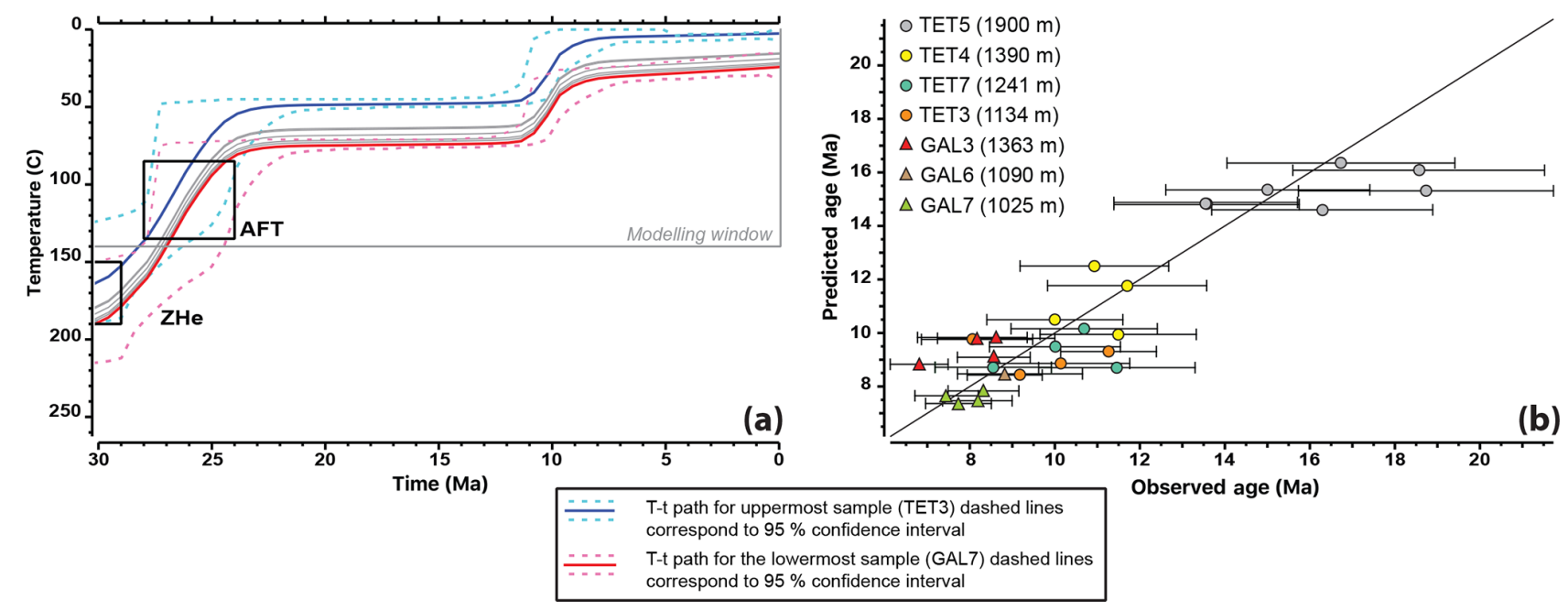

Figure 14. (a) Thermal history of the Têt fault footwall. Thermal modelling was computed with QTQt software (Gallagher, 2012) and Gautheron et al. (2009) diffusion parameters using AHe data from TET outside DZ samples and GAL DZ and outside DZ samples. AFT and ZHe data are from Maurel et al. (2008). (b) Predicted age vs. observed age graph for each apatite grain. The $1: 1$ diagonal line is for an ideal fit of these ages.

Although the number of analysed grains is limited, the homogeneity of the data suggests no significant hydrothermal circulations within the DZ in the last $10 \mathrm{Ma}$, in contrast to what the numerical models suggest (Taillefer et al., 2018). The presence of calcite-quartz-filled fractures and chloritization observed in the samples from this area might support more ancient (>10 Ma) hydrothermal circulation. Moreover, thermal modelling of GAL samples from both outside the DZ and in the outer DZ with QTQt software indicates a common history with the TET samples collected outside the DZ (Fig. 14). The modelled T-t path suggests rapid cooling $\left(25^{\circ} \mathrm{C} \mathrm{Ma}^{-1}\right)$ between 30 and $24 \mathrm{Ma}$, followed by a quiescent period and a second phase of cooling between 12 and $9 \mathrm{Ma}\left(15^{\circ} \mathrm{C} \mathrm{Ma}^{-1}\right)$ (Sect. S6 for model parameters). This model shows a good fit and is compatible with previous regional thermal histories indicating rapid cooling in the late Oligocene-early Miocene associated with the Têt fault activity during opening of the Gulf of Lion (Maurel et al., 2008; Milesi et al., 2019). At the scale of the eastern Pyrenees, the second exhumation phase can be associated with global $2 \mathrm{~km}$ uplift in the Tortonian suggested by Gunnell et al. (2009), which is likely coeval with a reactivation of the Têt fault around $10 \mathrm{Ma}$ (Cabrera et al., 1988; Mauffret et al., 2001). The good fit of the model supports the lack of a significant recent thermal anomaly along this segment of the Têt fault.

As fluid flow through fractured rocks is a highly heterogeneous process, even at the thin-section scale (Fig. 6), variable ${ }^{4} \mathrm{He}$ loss or gain by fluid advection can account for AHe age dispersion even in areas distant from present-day hot springs. This is supported by the global positive correlation between AHe rejuvenation and REE loss in samples from the Têt fault outer DZ footwall. The combination of AHe dating and REE analyses makes it possible to identify blind geothermal systems, possibly representing extensions of the present-day surficial ones, and thus to better constrain the geometry and intensity of recent geothermal anomalies along the Têt fault (Fig. 15). This result questions a straightforward interpretation of AHe ages if potential hydrothermal alteration is not considered.

\subsection{Hanging wall of the Têt fault}

Outside the hanging-wall DZ, apatites from samples ML1 and ST12 yield AHe ages (Table 2) consistent with previously published AHe ages in the Mont-Louis massif (Maurel et al., 2008), and REE patterns from sample ST12 are compatible with those of apatites from S-type granites (Sha and Chappell, 1999), with a moderate LREE depletion.

Within the hanging-wall DZ, samples closest to the Têt fault (TETHW, ST1, and GAL8) show scattering and mainly ageing of AHe ages, similar to the footwall inner DZ (Milesi et al., 2019). The AHe age scatter (Fig. 7; Table 2) cannot be properly modelled with a common thermal history (see Sect. S6). Apatite REE contents appear less variable within the hanging-wall DZ, except for a single apatite grain from the TETHW sample that yields a depleted REE pattern associated with the youngest AHe age. This result can be due to the hydrothermal influence of the Thuès-les-Bains hot springs in the footwall (Fig. 5) and to the same process of ${ }^{4} \mathrm{He}$ loss described in the footwall outer DZ (e.g. sample CAR7), thus suggesting the fault is not an impermeable barrier for fluids. We cannot exclude the possibility that fluid circulation in the hanging wall also played a role as attested by the presence of the Canaveilles hot springs just northeast of the TET profile (Taillefer et al., 2018). In this specific location (TET profile, gneiss-gneiss contact; Fig. 3) both the 


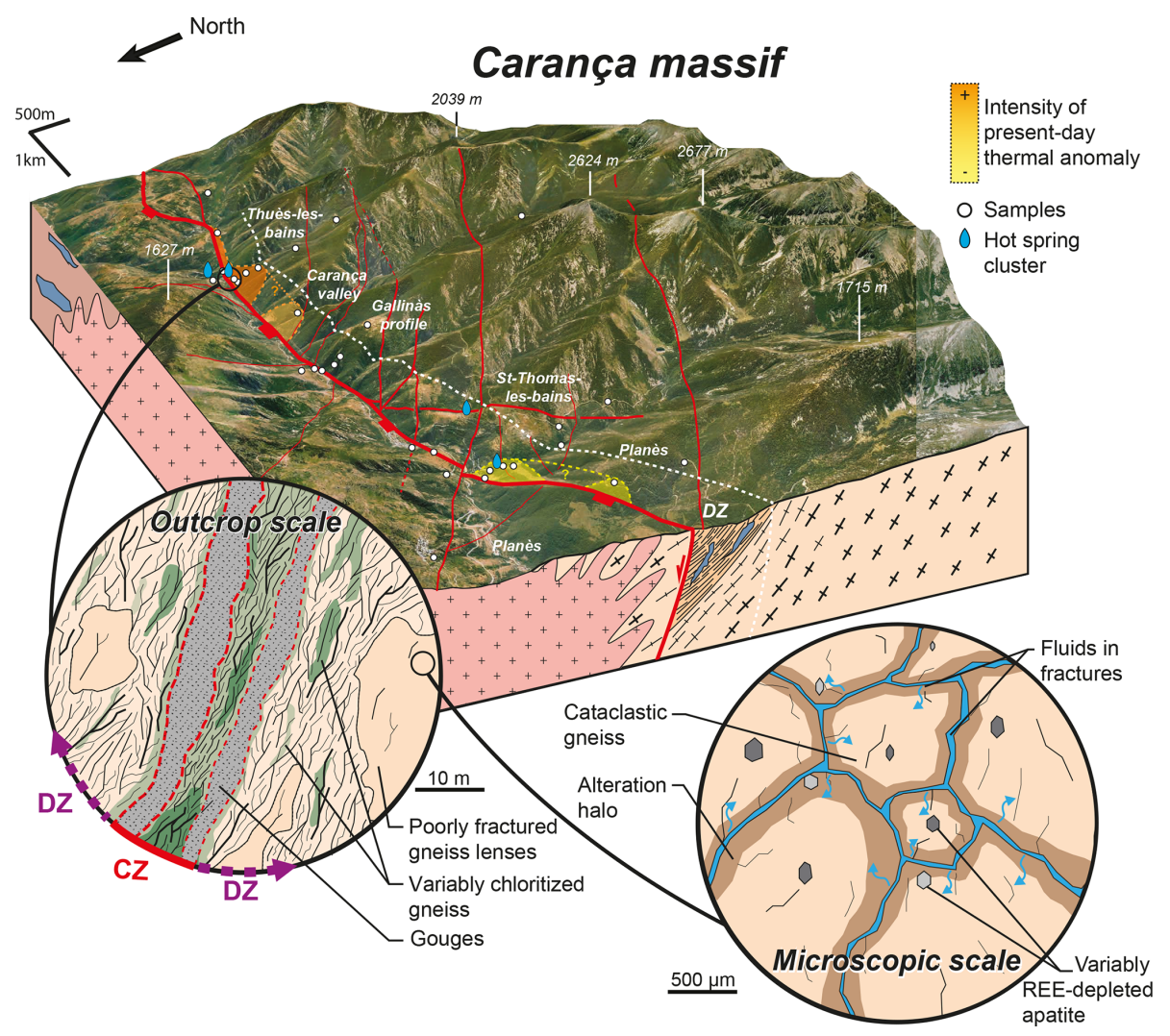

Figure 15. Schematic 3D block of the surface distribution of the present-day thermal anomalies in the Têt fault footwall based on AHe dating and REE analyses, with zooms into the fault zone at the outcrop and microscopic scale.

hanging-wall topographic gradient and the presence of permeable rocks might have contributed to a hydrothermal cell in the hanging wall.

Samples from the distal hanging-wall DZ yield less scattered AHe than those close to the Têt fault with the exception of sample PLA5. However, all samples including PLA5 exhibit very similar REE patterns. The intra-sample variation of AHe ages for PLA5 can be explained by a unique thermal history (see Sect. S6). Therefore, samples from the distal hanging-wall DZ (GAL1, GAL2, ST11, and ST14) are used in combination with those outside the DZ (ML1 and ST12) for modelling the thermal history of the hanging wall. The T-t path (Fig. 16) shows rapid cooling between 35 and $30 \mathrm{Ma}$ in the temperature range of 150 to $50^{\circ} \mathrm{C}$ and slow cooling since $30 \mathrm{Ma}$. Low cooling rates may account for the intrasample variation of AHe ages in the hanging wall away from the Têt fault in accordance with previous works (Fitzgerald et al., 2006; Maurel et al., 2008; Brown et al., 2013). Sample PLA5 is peculiar because it is the only sample located at a lower elevation than the Têt fault surface trace (Fig. 5). It is therefore located lower than the geothermal system along the Têt fault footwall in the Planès area. This peculiar location may account for the AHe age scattering and ageing within this sample outside the DZ, in addition to the more pronounced age dispersion compared to the footwall due to the above-mentioned regional slow cooling.

In the hanging wall, disturbed $\mathrm{AHe}$ ages are observed close to the Têt fault. Therefore, we consider AHe age dispersion within the hanging wall near the Têt fault to be potentially indicative of hydrothermal circulations within this part of the hanging wall even though the small number of samples does not allow for a clear interpretation. This questions the impermeable character of the hanging-wall rocks and the Têt fault gouges (Taillefer et al., 2017). However, the AHe perturbation is more limited than in the Têt fault footwall, without REE depletion for the GAL, ST, and PLA profiles, suggesting episodic circulation or thermal effects due to the increase in temperature in the Têt fault footwall. We show that moving away from the fault all samples outside the DZ share a common thermal history together with rocks far away from the fault (Fig. 16). This thermal modelling shows a rapid cooling event $\left(10^{\circ} \mathrm{C} \mathrm{Ma}^{-1}\right)$ between 36 and $30 \mathrm{Ma}$, followed by slow cooling under $4^{\circ} \mathrm{CMa}^{-1}$. Rapid cooling of the hanging wall at the end of the Eocene occurred contemporaneously with the thrusting of the Aston-Mont-Louis unit onto the Canigou massif (Ternois et al., 2019). 


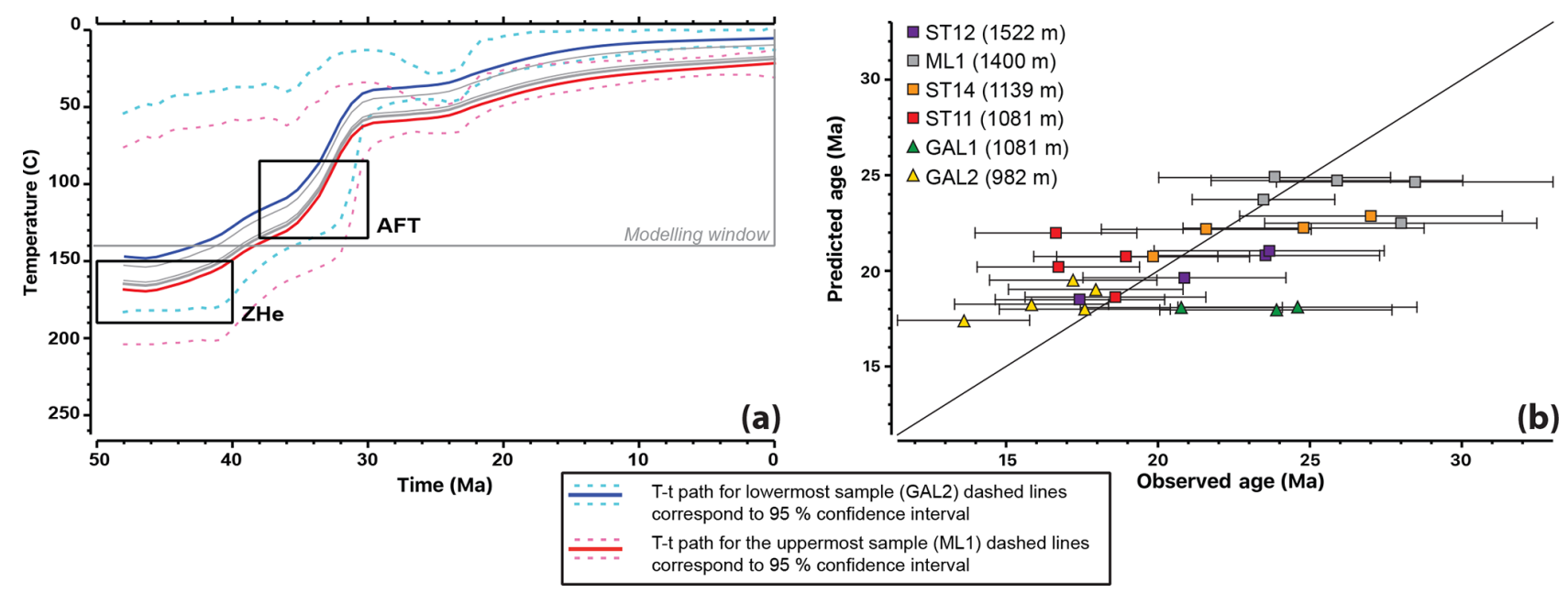

Figure 16. (a) Thermal history of the Têt fault hanging wall. Thermal modelling was computed with QTQt software (Gallagher, 2012) and Gautheron et al. (2009) diffusion parameters using AHe data from the HW except samples close to the Têt fault. AFT and ZHe data are from Maurel et al. (2008). (b) Predicted age vs. observed age graph for each apatite grain. The $1: 1$ diagonal line is for an ideal fit of these ages.

\section{Conclusions}

This coupled $(\mathrm{U}-\mathrm{Th}) / \mathrm{He}$ and REE study of a geothermal anomaly along the Têt normal fault confirms that the apatite thermochronometer can be impacted by local lowtemperature hydrothermal circulations along a dormant fault, as evidenced in our previous work (Milesi et al., 2019). It shows that apatites from samples in the fault DZ display large AHe age scattering and strong depletion of REE contents compared to apatites from samples located far away from the fault zone, which preserve the original REE patterns and the regional cooling history.

These results highlight the mobility of REE in apatite during interaction with hydrothermal fluids, demonstrating that apatite grains can no longer be considered a closed system in such a context. AHe age dispersion due to ${ }^{4} \mathrm{He}$ loss or gain may be induced primarily by fluid advection rather than by a thermal diffusion process as usually considered in nonhydrothermal environments. As fluid flow through fractured rocks is a highly heterogeneous process, even at the thinsection scale, variable ${ }^{4} \mathrm{He}$ mobility can account for large inter- and intra-sample $\mathrm{AHe}$ age dispersion.

This study also shows that even in the absence of surface hydrothermal activity, AHe ages can be affected by recent blind hydrothermal systems. This questions the interpretation of AHe ages when hydrothermal alteration is not carefully considered even when evidence of active fluid circulations is lacking.

The combined use of AHe thermochronology with apatite REE analysis appears to be an efficient tool to identify the open-system behaviour of apatite grains in relation to hydrothermal fluid circulations. This approach provides information on the origin of AHe age scattering, thus allowing for the selection of proper AHe ages and rejection of others cor- responding to reset apatites. This mode of age selection can be applied for thermal modelling calculations. We propose that this coupling of AHe ages with REE analyses should be generalized in low-temperature thermochronological studies of areas susceptible to having suffered hydrothermal overprint. Moreover, this methodological coupling could be a way to look for geothermal systems in addition to other approaches including water geochemistry, geophysical surveys, well drilling, or numerical modelling. In the present study, the thermal anomalies are restricted to two main hot spring clusters along the fault in contrast to a previous thermal numerical modelling, which suggested a more regular distribution of a single thermal anomaly along the fault. Moreover, this coupling shows that the AHe age dispersion and REE depletion are more pronounced in one cluster with abundant hot springs, thus providing additional constraints on the intensity and geometry of this localized geothermal anomaly. However, its sensitiveness to hydrothermal fluid flow variations through space and time has to be further explored

$\mathrm{AHe}$ ages from the hanging wall and the footwall remain unaffected by recent hydrothermal perturbation and can be used to restore the cooling history on both sides of the Têt fault. In the hanging wall of the Mont-Louis massif, $\mathrm{AHe}$ ages record Eocene fast cooling related to the main collision event in the eastern Pyrenees. In the footwall of the Carança and Canigou massifs, two main phases of cooling in relation to the Têt fault normal activity are recognized: (i) between 30 and $24 \mathrm{Ma}$ in agreement with previous thermochronological studies and (ii) a second one around $10 \mathrm{Ma}$ that is reported for the first time in the eastern Pyrenees. This second cooling phase is coeval with a major episode of regional uplift in the eastern Pyrenees. 
Data availability. Data that support the findings of this study are available in the Supplement. Additional details may be obtained upon request from the corresponding author, Gaétan Milesi (gaetan.milesi@umontpellier.fr).

Supplement. The supplement related to this article is available online at: https://doi.org/10.5194/se-11-1747-2020-supplement.

Author contributions. MBo supervised the helium analyses, OB and CM supervised the ICPMS analyses. AT did the field and numerical models on fluid and heat transfer, and MBe co-wrote the project and participated in its funding. PMü participated in the analysis of the thermochronological and REE data, PMo and RS are the $\mathrm{PhD}$ directors and scientific advisors, and GM is the PhD student who conducted the main part of the field and laboratory work.

Competing interests. The authors declare that they have no conflict of interest.

Special issue statement. This article is part of the special issue "Faults, fractures, and fluid flow in the shallow crust". It is not associated with a conference.

Acknowledgements. Thanks for technical support go to Doriane Delmas and Christophe Nevado for thin-section preparation, Lucie Koeller and Léa Causse for ICP-MS analyses, and Cyprien Astoury for apatite separation. Thanks to the inhabitants of Thuès-EntreValls for their welcome during fieldwork. Special thanks to Meinert Rahn and Cécile Gautheron for their constructive comments and the improvement of this paper.

Financial support. This research has been supported by the THERMOFAULT, a project supported by the Region Occitanie (France) involving TLS Geothermics (main sponsor), Géosciences Montpellier, and the TelluS Program of CNRS/INSU.

Review statement. This paper was edited by Fabrizio Balsamo and reviewed by Cecile Gautheron and Meinert Rahn.

\section{References}

Agosta, F., Prasad, M., and Aydin, A.: Physical properties of carbonate fault rocks, fucino basin (Central Italy): implications for fault seal in platform carbonates, Geofluids, 7, 19-32, https://doi.org/10.1111/j.1468-8123.2006.00158.x, 2007.

Andrews, J. N. and Lee, D. J.: Inert gases in groundwater from the Bunter Sandstone of England as indicators of age and palaeoclimatic trends, J. Hydrol., 41, 233-252, https://doi.org/10.1016/0022-1694(79)90064-7, 1979.
Ault, A. K., Gautheron, C., and King, G. E.: Innovations in $(\mathrm{U}-\mathrm{Th}) / \mathrm{He}$, Fission Track, and Trapped Charge Thermochronometry with Applications to Earthquakes, Weathering, Surface Connections, and the Growth and Decay of Mountains, Tectonics, 38, 3705-3739, https://doi.org/10.1029/2018TC005312, 2019.

Ballas, G., Soliva, R., Sizun, J.-P., Benedicto, A., Cavailhes, T., and Raynaud, S.: The importance of the degree of cataclasis in shear bands for fluid flow in porous sandstone, Provence, France, AAPG Bull., 96, 2167-2186, https://doi.org/10.1306/04051211097, 2012.

Ballouard, C., Poujol, M., Boulvais, P., Mercadier, J., Tartèse, R., Venneman, T., Deloule, E., Jolivet, M., Kéré, I., Cathelineau, M., and Cuney, M.: Magmatic and hydrothermal behavior of uranium in syntectonic leucogranites: The uranium mineralization associated with the Hercynian Guérande granite (Armorican Massif, France), Ore Geology Reviews, 80, 309-331, https://doi.org/10.1016/j.oregeorev.2016.06.034, 2017.

Barbey, P., Cheilletz, A., and Laumonier, B.: The Canigou orthogneisses (Eastern Pyrenees, France, Spain): an Early Ordovician rapakivi granite laccolith and its contact aureole, Comptes Rendus de l'Académie des Sciences - Series IIA, Earth Planet. Sc., 332, 129-136, https://doi.org/10.1016/S12518050(00)01506-8, 2001.

Barbier, E.: Geothermal energy technology and current status: an overview, Renewable and Sustainable Energy Reviews, 6, 3-65, https://doi.org/10.1016/S1364-0321(02)00002-3, 2002.

Belousova, E. A., Griffin, W. L., O'Reilly, S. Y., and Fisher, N. I.: Apatite as an indicator mineral for mineral exploration: trace-element compositions and their relationship to host rock type, Journal of Geochemical Exploration, 76, 45-69, https://doi.org/10.1016/S0375-6742(02)00204-2, 2002.

Bense, V. F., Gleeson, T., Loveless, S. E., Bour, O., and Scibek, J.: Fault zone hydrogeology, Earth-Sci. Rev., 127, 171-192, https://doi.org/10.1016/j.earscirev.2013.09.008, 2013.

Berg, S. S. and Skar, T.: Controls on damage zone asymmetry of a normal fault zone: outcrop analyses of a segment of the Moab fault, SE Utah, J. Struct. Geol., 27, 1803-1822, https://doi.org/10.1016/j.jsg.2005.04.012, 2005.

Bertani, R.: Geothermal power generation in the world 2005-2010 update report, Geothermics, 41, 1-29, https://doi.org/10.1016/j.geothermics.2011.10.001, 2012.

Billi, A., Salvini, F., and Storti, F.: The damage zone-fault core transition in carbonate rocks: implications for fault growth, structure and permeability, J. Struct. Geol., 25, 1779-1794, https://doi.org/10.1016/S0191-8141(03)00037-3, 2003.

Blackwell, D. D., Golan, B., and Beniot, D.: Thermal regime in the Dixie valley geothermal system, Proceedings World Geothermal Congress 2000, 6, 2000.

Boulvais, P., Ruffet, G., Cornichet, J., and Mermet, M.: Cretaceous albitization and dequartzification of Hercynian peraluminous granite in the Salvezines Massif (French Pyrénées), Lithos, 93, 89-106, https://doi.org/10.1016/j.lithos.2006.05.001, 2007.

Boutin, A., de Saint Blanquat, M., Poujol, M., Boulvais, P., de Parseval, P., Rouleau, C., and Robert, J.-F.: Succession of Permian and Mesozoic metasomatic events in the eastern Pyrenees with emphasis on the Trimouns talc-chlorite deposit, Int. J. Earth Sci., 105, 747-770, https://doi.org/10.1007/s00531-015-1223-x, 2016. 
Brown, R. W., Beucher, R., Roper, S., Persano, C., Stuart, F., and Fitzgerald, P.: Natural age dispersion arising from the analysis of broken crystals, Part I: Theoretical basis and implications for the apatite $(\mathrm{U}-\mathrm{Th}) / \mathrm{He}$ thermochronometer, Geochim. Cosmoch. Ac., 122, 478-497, https://doi.org/10.1016/j.gca.2013.05.041, 2013.

Bruguier, O., Becq-Giraudon, J. F., Champenois, M., Deloule, E., Ludden, J., and Mangin, D.: Application of in situ zircon geochronology and accessory phase chemistry to constraining basin development during post-collisional extension: a case study from the French Massif Central, Chem. Geol., 201, 319336, https://doi.org/10.1016/j.chemgeo.2003.08.005, 2003.

Burbank, D. W., Puigdefàbregas, C. A. I., and Munoz, J. A.: The chronology of the Eocene tectonic and stratigraphic development of the eastern Pyrenean foreland basin, northeast Spain, Geol. Soc. Am. Bull., 104, 1101-1120, 1992.

Cabrera, L., Roca, E., and Santanach, P.: Basin formation at the end of a strike-slip fault: the Cerdanya Basin (eastern Pyrenees), J. Geol. Soc., 145, 261-268, 1988.

Caine, J. S., Evans, J. P., and Forster, C. B.: Fault zone architecture and permeability structure, Geology, 24, 1025, https://doi.org/10.1130/00917613(1996)024<1025:FZAAPS>2.3.CO;2, 1996.

Caine, J. S. and Tomusiak, S. R. A.: Brittle structures and their role in controlling porosity and permeability in a complex Precambrian crystalline-rock aquifer system in the Colorado Rocky Mountain Front Range, Geol. Soc. Am. Bull., 115, 1410, https://doi.org/10.1130/B25088.1, 2003.

Carozza, J.-M. and Baize, S.: L'escarpement de faille de la Têt est-il le résultat de la tectonique active Plio-Pléistocène ou d'une exhumation Pléistocène?, Comptes Rendus Geoscience, 336, $217-$ 226, https://doi.org/10.1016/j.crte.2003.10.026, 2004.

Castiñeiras, P., Navidad, M., Casas, J. M., Liesa, M., and Carreras, J.: Petrogenesis of Ordovician Magmatism in the Pyrenees (Albera and Canigó Massifs) Determined on the Basis of Zircon Minor and Trace Element Composition, J. Geol., 119, 521-534, https://doi.org/10.1086/660889, 2011.

Chew, D. M., Babechuk, M. G., Cogné, N., Mark, C., O’Sullivan, G. J., Henrichs, I. A., Doepke, D., and McKenna, C. A.: (LA,Q)-ICPMS trace-element analyses of Durango and McClure Mountain apatite and implications for making natural LA-ICPMS mineral standards, Chem. Geol., 435, 35-48, https://doi.org/10.1016/j.chemgeo.2016.03.028, 2016.

Clauzon, G., Le Strat, P., Duvail, C., Do Couto, D., Suc, J.-P., Molliex, S., Bache, F., Besson, D., Lindsay, E. H., Opdyke, N. D., Rubino, J.-L., Popescu, S.-M., Haq, B. U., and Gorini, C.: The Roussillon Basin (S. France): A case-study to distinguish local and regional events between 6 and $3 \mathrm{Ma}$, Mar. Petrol. Geol., 66, 18-40, https://doi.org/10.1016/j.marpetgeo.2015.03.012, 2015.

Cocherie, A., Baudin, T., Autran, A., Guerrot, C., Fanning, C. M., and Laumonier, B.: U-Pb zircon (ID-TIMS and SHRIMP) evidence for the early ordovician intrusion of metagranites in the late Proterozoic Canaveilles Group of the Pyrenees and the Montagne Noire (France), Bulletin de la Société Géologique de France, 176, 269-282, https://doi.org/10.2113/176.3.269, 2005.

Cox, S. C., Menzies, C. D., Sutherland, R., Denys, P. H., Chamberlain, C., and Teagle, D. A. H.: Changes in hot spring temperature and hydrogeology of the Alpine Fault hanging wall, New
Zealand, induced by distal South Island earthquakes, Geofluids, 15, 216-239, https://doi.org/10.1111/gfl.12093, 2015.

Cramer, J. J. and Nesbitt, H. W.: Mass-balance relations and traceelement mobility during continental weathering of various igneous rocks, Sci. Géol., 73, 63-73, 1983.

Craw, D., Upton, P., Horton, T., and Williams, J.: Migration of hydrothermal systems in an evolving collisional orogen, New Zealand, Mineralium Deposita, 48, 233-248, https://doi.org/10.1007/s00126-012-0421-8, 2013.

Cuney, M.: Evolution of Uranium Fractionation Processes through Time: Driving the Secular Variation of Uranium Deposit Types, Economic Geology, 105, 553-569, https://doi.org/10.2113/gsecongeo.105.3.553, 2010.

Danišík, M., Fodor, L., Dunkl, I., Gerdes, A., Csizmeg, J., HámorVidó, M., and Evans, N. J.: A multi-system geochronology in the Ad-3 borehole, Pannonian Basin (Hungary) with implications for dating volcanic rocks by low-temperature thermochronology and for interpretation of (U-Th)/He data, Terra Nova, 27, 258-269, https://doi.org/10.1111/ter.12155, 2015.

Delmas, M., Calvet, M., Gunnell, Y., Voinchet, P., Manel, C., Braucher, R., Tissoux, H., Bahain, J.-J., Perrenoud, C., and Saos, T.: Terrestrial $10 \mathrm{Be}$ and electron spin resonance dating of fluvial terraces quantifies quaternary tectonic uplift gradients in the eastern Pyrenees, Quaternary Sci. Rev., 193, 188-211, https://doi.org/10.1016/j.quascirev.2018.06.001, 2018.

Deming, D.: Fluid flow and heat transport in the upper continental crust, Geological Society, London, Special Publications, 78, 27 42, https://doi.org/10.1144/GSL.SP.1994.078.01.04, 1994.

Dobson, P. F.: A Review of Exploration Methods for Discovering Hidden Geothermal Systems, GRC Transactions, 40, 695-706, 2016.

Eichhubl, P., Davatzes, N. C., and Becker, S. P.: Structural and diagenetic control of fluid migration and cementation along the Moab fault, Utah, AAPG Bulletin, 93, 653-681, https://doi.org/10.1306/02180908080, 2009.

Fallourd, S., Poujol, M., Boulvais, P., Paquette, J.-L., de Saint Blanquat, M., and Rémy, P.: In situ LA-ICP-MS U-Pb titanite dating of $\mathrm{Na}-\mathrm{Ca}$ metasomatism in orogenic belts: the North Pyrenean example, Int. J. Earth Sci., 103, 667-682, https://doi.org/10.1007/s00531-013-0978-1, 2014.

Farley, K. A., Wolf, R. A., and Silver, L. T.: The effects of long alpha-stopping distances on (U-Th)/He ages, Geochim. Cosmochim. Ac., 60, 4223-4229, https://doi.org/10.1016/S00167037(96)00193-7, 1996.

Faulds, J. E., Price, L. M., Snee, L. W., Gans, P. B., Umhoefer, P. J., Beard, L. S., and Lamb, M. A.: A chronicle of Miocene extension near the Colorado Plateau-Basin and Range boundary, southern White Hills, northwestern Arizona: Paleogeographic and tectonic implications, Miocene Tectonics of the Lake Mead Region, Central Basin and Range: Geological Society of America Special Paper, 463, 87-119. 2010.

Faulds, J. and Hinz, N.: Favorable Tectonic and Structural Settings of Geothermal Systems in the Great Basin Region, Western USA: Proxies for Discovering Blind Geothermal Systems, Proceedings World Geothermal Congress 2015, 1-6, 2015.

Faulkner, D. R., Jackson, C. A. L., Lunn, R. J., Schlische, R. W., Shipton, Z. K., Wibberley, C. A. J., and Withjack, M. O.: A review of recent developments concerning the structure, mechan- 
ics and fluid flow properties of fault zones, J. Struct. Geol., 32, 1557-1575, https://doi.org/10.1016/j.jsg.2010.06.009, 2010.

Favara, R., Grassa, F., Inguaggiato, S., and Valenza, M.: Hydrogeochemistry and stable isotopes of thermal springs: earthquakerelated chemical changes along Belice Fault (Western Sicily), Appl. Geochem., 16, 1-17, https://doi.org/10.1016/S08832927(00)00015-9, 2001.

Fillon, C. and van der Beek, P.: Post-orogenic evolution of the southern Pyrenees: constraints from inverse thermokinematic modelling of low-temperature thermochronology data, Basin Res., 24, 418-436, https://doi.org/10.1111/j.13652117.2011.00533.x, 2012.

Fisher, Q. J. and Knipe, R. J.: Fault sealing processes in siliciclastic sediments, Geological Society, London, Special Publications, 147, 117-134, https://doi.org/10.1144/GSL.SP.1998.147.01.08, 1998.

Fitzgerald, P. G., Muñoz, J. A., Coney, P. J., and Baldwin, S. L.: Asymmetric exhumation across the Pyrenean orogen: implications for the tectonic evolution of a collisional orogen, Earth Planet. Sc. Lett., 173, 157-170, https://doi.org/10.1016/S0012821X(99)00225-3, 1999.

Fitzgerald, P. G., Baldwin, S. L., Webb, L. E., and O'Sullivan, P. B.: Interpretation of $(\mathrm{U}-\mathrm{Th}) / \mathrm{He}$ single grain ages from slowly cooled crustal terranes: A case study from the Transantarctic Mountains of southern Victoria Land, Chem. Geol., 225, 91-120, https://doi.org/10.1016/j.chemgeo.2005.09.001, 2006.

Flowers, R. M., Ketcham, R. A., Shuster, D. L., and Farley, K. A.: Apatite (U-Th)/He thermochronometry using a radiation damage accumulation and annealing model, Geochim. Cosmochim. Ac., 73, 2347-2365, https://doi.org/10.1016/j.gca.2009.01.015, 2009.

Forster, C. and Smith, L.: The influence of groundwater flow on thermal regimes in mountainous terrain: A model study, J. Geophys. Res., 94, 9439, https://doi.org/10.1029/JB094iB07p09439, 1989.

Förster, H.-J.: The chemical composition of REE-Y-Th-U-rich accessory minerals in peraluminous granites of the ErzgebirgeFichtelgebirge region, Germany; Part I, The monazite-(Ce)brabantite solid solution series, American Mineralogist, 83, 259272, https://doi.org/10.2138/am-1998-3-409, 1998.

Fossen, H. and Rotevatn, A.: Fault linkage and relay structures in extensional settings - A review, Earth-Sci. Rev., 154, 14-28, https://doi.org/10.1016/j.earscirev.2015.11.014, 2016.

Gallagher, K.: Transdimensional inverse thermal history modeling for quantitative thermochronology, J. Geophys. Res.-Sol. Ea., 117, 16, https://doi.org/10.1029/2011JB008825, 2012.

Gastil, RG., De Lisle, M., and Morgan, J.: Some Effects of Progressive Metamorphism on Zircons, Geol. Soc. Am. Bull., 78, 879, https://doi.org/10.1130/00167606(1967)78[879:SEOPMO]2.0.CO;2, 1967.

Gautheron, C., Tassan-Got, L., Barbarand, J., and Pagel, M.: Effect of alpha-damage annealing on apatite (U-Th)/He thermochronology, Chem. Geol., 266, 157-170, https://doi.org/10.1016/j.chemgeo.2009.06.001, 2009.

Gautheron, C. and Tassan-Got, L.: A Monte Carlo approach to diffusion applied to noble gas/helium thermochronology, Chem. Geol., 273, 212-224, https://doi.org/10.1016/j.chemgeo.2010.02.023, 2010.
Gibert, J. M. D., Dom, R., and Martinell, J.: Bioerosion in shell beds from the Pliocene Roussillon Basin, France: Implications for the (macro)bioerosion ichnofacies model, Acta Palaeontologica Polonica, 16, 783-798, 2007.

Gibson, M., Sinclair, H. D., Lynn, G. J., and Stuart, F. M.: Late- to post-orogenic exhumation of the Central Pyrenees revealed through combined thermochronological data and modelling, Basin Res., 19, 323-334, https://doi.org/10.1111/j.13652117.2007.00333.x, 2007.

Gieré, R.: Hydrothermal mobility of Ti, $\mathrm{Zr}$ and REE: examples from the Bergell and Adamello contact aureoles (Italy), Terra Nova, 2, 60-67, https://doi.org/10.1111/j.1365-3121.1990.tb00037.x, 1990.

Gorynski, K. E., Walker, J. D., Stockli, D. F., and Sabin, A.: Apatite (U-Th)/He thermochronometry as an innovative geothermal exploration tool: A case study from the southern Wassuk Range, Nevada, Journal of Volcanology and Geothermal Research, 270, 99-114, https://doi.org/10.1016/j.jvolgeores.2013.11.018, 2014.

Grasby, S. E. and Hutcheon, I.: Controls on the distribution of thermal springs in the southern Canadian cordillera, Canadian Journal of Earth Sciences, 38, 427-440. 2001.

Griffiths, L., Heap, M. J., Wang, F., Daval, D., Gilg, H. A., Baud, P., Schmittbuhl, J., and Genter, A.: Geothermal implications for fracture-filling hydrothermal precipitation, Geothermics, 64, 235-245, https://doi.org/10.1016/j.geothermics.2016.06.006, 2016.

Gunnell, Y., Calvet, M., Brichau, S., Carter, A., Aguilar, J.-P., and Zeyen, H.: Low long-term erosion rates in high-energy mountain belts: Insights from thermo- and biochronology in the Eastern Pyrenees, Earth Planet. Sc. Lett., 278, 208-218, https://doi.org/10.1016/j.epsl.2008.12.004, 2009.

Harlov, D. E., Richard Wirth, R., and Förster H.-J.: An experimental study of dissolution-reprecipitation in fluorapatite: fluid infiltration and the formation of monazite, Contrib. Mineral Petrol., 150, 268-286, https://doi.org/10.1007/s00410-005-0017-8, 2005.

Heffington, W. M., Kline, J. M., and Rottman, J. W.: Volcanoes as a source of geothermal energy, Energy, 2, 457-459, https://doi.org/10.1016/0360-5442(77)90008-1, 1977.

Henrichs, I. A., O’Sullivan, G., Chew, D. M., Mark, C., Babechuk, M. G., McKenna, C., and Emo, R.: The trace element and U-Pb systematics of metamorphic apatite, Chem. Geol., 483, 218-238, https://doi.org/10.1016/j.chemgeo.2017.12.031, 2018.

Hoÿm de Marien, L., Le Bayon, B., Pitra, P., Van Den Driessche, J., Poujol, M., and Cagnard, F.: Two Variscan metamorphism in the Canigou massif: Evidence for crustal thickening in the Pyrenees, Journal of Metamorphic Geology, 37, 863-888, https://doi.org/10.1111/jmg.12487, 2019.

Janots, E., Grand'Homme, A., Bernet, M., Guillaume, D., Gnos, E., Boiron, M.-C., Rossi, M., Seydoux-Guillaume, A.-M., and De Ascenção Guedes, R.: Geochronological and thermometric evidence of unusually hot fluids in an Alpine fissure of Lauzière granite (Belledonne, Western Alps), Solid Earth, 10, 211-223, https://doi.org/10.5194/se-10-211-2019, 2019.

Jochum, K. P., Seufert, H. M., and Thirlwall, M. F.: Highsensitivity $\mathrm{Nb}$ analysis by spark-source mass spectrometry (SSMS) and calibration of XRF $\mathrm{Nb}$ and $\mathrm{Zr}$, Chem. Geol., 81, 1-16, https://doi.org/10.1016/0009-2541(90)90035-6, 1990.

Jordan, T. A., Martin, C., Ferraccioli, F., Matsuoka, K., Corr, H., Forsberg, R., Olesen, A., and Siegert, M.: Anomalously 
high geothermal flux near the South Pole, Sci. Rep., 8, https://doi.org/10.1038/s41598-018-35182-0, 2018.

Ketcham, R. A., Gautheron, C., and Tassan-Got, L.: Accounting for long alpha-particle stopping distances in (U-Th-Sm)/He geochronology: Refinement of the baseline case, Geochim. Cosmochim. Ac., 75, 7779-7791, https://doi.org/10.1016/j.gca.2011.10.011, 2011

Kim, Y.-S., Peacock, D. C. P., and Sanderson, D. J.: Fault damage zones, J. Struct. Geol., 26, 503-517, https://doi.org/10.1016/j.jsg.2003.08.002, 2004.

Krimissa, M.: Application des méthodes isotopiques a l'étude des eaux thermales en milieu granitique (Pyrénées, France), Orsay Paris-Sud., 248 pp., 1992.

Lacan, P. and Ortuño, M.: Active Tectonics of the Pyrenees: A review, Journal of Iberian Geology, 38, https://doi.org/10.5209/rev_JIGE.2012.v38.n1.39203, 2012.

Louis, S., Luijendijk, E., Dunkl, I., and Person, M.: Episodic fluid flow in an active fault, Geology, 47, 938-942, https://doi.org/10.1130/G46254.1, 2019.

Lund, J. W., Freeston, D. H., and Boyd, T. L.: Direct utilization of geothermal energy 2010 worldwide review, Geothermics, 40, 159-180, https://doi.org/10.1016/j.geothermics.2011.07.004, 2011.

Masson, C., Mazzotti, S., Vernant, P., and Doerflinger, E.: Extracting small deformation beyond individual station precision from dense Global Navigation Satellite System (GNSS) networks in France and western Europe, Solid Earth, 10, 19051920, https://doi.org/10.5194/se-10-1905-2019, 2019.

Mauffret, A., de Grossouvre, B. D., Dos Reis, A. T., Gorini, C., and Nercessian, A.: Structural geometry in the eastern Pyrenees and western Gulf of Lion (Western Mediterranean), J. Struct. Geol., 23, 1701-1726, 2001.

Maurel, O., Monié, P., Pik, R., Arnaud, N., Brunel, M., and Jolivet, M.: The Meso-Cenozoic thermo-tectonic evolution of the Eastern Pyrenees: an ${ }^{40} \mathrm{Ar} /{ }^{39} \mathrm{Ar}$ fission track and (U-Th)/He thermochronological study of the Canigou and Mont-Louis massifs, Int. J. Earth Sci., 97, 565-584, https://doi.org/10.1007/s00531007-0179-x, 2008.

Mayolle, S., Soliva, R., Caniven, Y., Wibberley, C., Ballas, G., Milesi, G., and Dominguez, S.: Scaling of fault damage zones in carbonate rocks, J. Struct. Geol., 124, 35-50, https://doi.org/10.1016/j.jsg.2019.03.007, 2019.

McCay, A. T., Shipton, Z. K., Lunn, R. J., and Gale, J. F.: Mini thief zones: Subcentimeter sedimentary features enhance fracture connectivity in shales, AAPG Bulletin, 103, 951-971, https://doi.org/10.1306/0918181610617114, 2019.

McDowell, F. W., McIntosh, W. C., and Farley, K. A.: A precise ${ }^{40} \mathrm{Ar}-{ }^{39} \mathrm{Ar}$ reference age for the Durango apatite (U-Th)/He and fission-track dating standard, Chem. Geol., 214, 249-263, https://doi.org/10.1016/j.chemgeo.2004.10.002, 2005.

McKenna, J. R. and Blackwell, D. D.: Numerical modeling of transient Basin and Range extensional geothermal systems, Geothermics, 33, 457-476, https://doi.org/10.1016/j.geothermics.2003.10.001, 2004.

Metcalf, J. R., Fitzgerald, P. G., Baldwin, S. L., and Muñoz, J.-A.: Thermochronology of a convergent orogen: Constraints on the timing of thrust faulting and subsequent exhumation of the Maladeta Pluton in the Central Pyre- nean Axial Zone, Earth Planet. Sc. Lett., 287, 488-503, https://doi.org/10.1016/j.epsl.2009.08.036, 2009.

Meixner, J., Schill, E., Grimmer, J. C., Gaucher, E., Kohl, T., and Klingler, P.: Structural control of geothermal reservoirs in extensional tectonic settings: An example from the Upper Rhine Graben, J. Struct. Geol., 82, 1-15, https://doi.org/10.1016/j.jsg.2015.11.003, 2016.

Milesi, G., Soliva, R., Monié, P., Münch, P., Bellanger, M., Bruguier, O., Bonno, M., Taillefer, A., and Mayolle, S.: Mapping a geothermal anomaly using apatite (U/Th)/He thermochronology in the Têt fault damage zone, eastern Pyrenees, France, Terra Nova, 31, 569-576, https://doi.org/10.1111/ter.12429, 2019.

Paternoster, M., Oggiano, G., Sinisi, R., Caracausi, A., and Mongelli, G.: Geochemistry of two contrasting deep fluids in the Sardinia microplate (western Mediterranean): Relationships with tectonics and heat sources, Journal of Volcanology and Geothermal Research, 336, 108-117, https://doi.org/10.1016/j.jvolgeores.2017.02.011, 2017.

Petit, C. and Mouthereau, F.: Steep topographic slope preservation by anisotropic diffusion: An example from the Neogene Têt fault scarp, eastern Pyrenees, Geomorphology, 171, 173-179, https://doi.org/10.1016/j.geomorph.2012.05.016, 2012.

Petit, V., Le Goff, E., and Brisset, N.: Avec la collaboration de - Ressource en eau thermale des Thermes de Vernet-LesBains: État des lieux (Pyrénées Orientales), BRGM/RP-59182FR, p. 73, 20 ill., 5 ann. 2014.

Poujol, M., Boulvais, P., and Kosler, J.: Regional-scale Cretaceous albitization in the Pyrenees: evidence from in situ U-Th-Pb dating of monazite, titanite and zircon, J. Geol. Soc., 167, 751-767, https://doi.org/10.1144/0016-76492009-144, 2010.

Roche, V., Sternai, P., Guillou-Frottier, L., Menant, A., Jolivet, L., Bouchot, V., and Gerya, T.: Emplacement of metamorphic core complexes and associated geothermal systems controlled by slab dynamics, Earth Planet. Sc. Lett., 498, 322-333, https://doi.org/10.1016/j.epsl.2018.06.043, 2018.

Sartégou, A., Bourlès, D. L., Blard, P.-H., Braucher, R., Tibari, B., Zimmermann, L., Leanni, L., Aumaître, G., and Keddadouche, K.: Deciphering landscape evolution with karstic networks: A Pyrenean case study, Quat. Geochronol., 43, 12-29, https://doi.org/10.1016/j.quageo.2017.09.005, 2018.

Séranne, M., Benedicto, A., Labaum, P., Truffert, C., and Pascal, G.: Structural style and evolution of the Gulf of Lion Oligo-Miocene rifting: Role of the Pyrenean orogeny, Mar. Petrol. Geol., 12, 809-820, 1995.

Sha, L.-K. and Chappell, B. W.: Apatite chemical composition, determined by electron microprobe and laser-ablation inductively coupled plasma mass spectrometry, as a probe into granite petrogenesis, Geochim. Cosmochim. Ac., 63, 3861-3881, https://doi.org/10.1016/S0016-7037(99)00210-0, 1999.

Shipton, Z. K. and Cowie, P. A.: Damage zone and slip-surface evolution over $\mu \mathrm{m}$ to $\mathrm{km}$ scales in high-porosity Navajo sandstone, Utah, J. Struct. Geol., 23, 1825-1844, 2001.

Shuster, D. L. and Farley, K. A.: The influence of artificial radiation damage and thermal annealing on helium diffusion kinetics in apatite, Geochim. Cosmochim. Ac., 73, 183-196, https://doi.org/10.1016/j.gca.2008.10.013, 2009.

Sibson, R. H.: Fluid involvement in normal faulting, J. Geodynam., 29, 469-499, https://doi.org/10.1016/S0264-3707(99)00042-3, 2000. 
Sibuet, J.-C., Srivastava, S. P., and Spakman, W.: Pyrenean orogeny and plate kinematics: Pyrenean orogeny and plate kinematics, J. Geophys. Res.-Sol. Ea., 109, B08104, https://doi.org/10.1029/2003JB002514, 2004.

Sinclair, H. D.: Asymmetric growth of the Pyrenees revealed through measurement and modeling of orogenic fluxes, Am. J. Sci., 305, 369-406, https://doi.org/10.2475/ajs.305.5.369, 2005.

Souriau, A. and Pauchet, H.: A new synthesis of Pyrenean seismicity and its tectonic implications, Tectonophysics, 290, 221-244, https://doi.org/10.1016/S0040-1951(98)00017-1, 1998

Sun, S. S. and McDonough, W. F.: Chemical and isotopic systematics of oceanic basalts: implications for mantle composition and processes, Geological Society, London, Special Publications, 42, 313-345, https://doi.org/10.1144/GSL.SP.1989.042.01.19, 1989.

Sutherland, R., Townend, J., Toy, V., Upton, P., Coussens, J., Allen, M., Baratin, L.-M., Barth, N., Becroft, L., Boese, C., Boles, A., Boulton, C., Broderick, N. G. R., Janku-Capova, L., Carpenter, B. M., Célérier, B., Chamberlain, C., Cooper, A., Coutts, A., Cox, S., Craw, L., Doan, M.-L., Eccles, J., Faulkner, D., Grieve, J., Grochowski, J., Gulley, A., Hartog, A., Howarth, J., Jacobs, K., Jeppson, T., Kato, N., Keys, S., Kirilova, M., Kometani, Y., Langridge, R., Lin, W., Little, T., Lukacs, A., Mallyon, D., Mariani, E., Massiot, C., Mathewson, L., Melosh, B., Menzies, C., Moore, J., Morales, L., Morgan, C., Mori, H., Niemeijer, A., Nishikawa, O., Prior, D., Sauer, K., Savage, M., Schleicher, A., Schmitt, D. R., Shigematsu, N., Taylor-Offord, S., Teagle, D., Tobin, H., Valdez, R., Weaver, K., Wiersberg, T., Williams, J., Woodman, N., and Zimmer, M.: Extreme hydrothermal conditions at an active plate-bounding fault, Nature, 546, 137-140, https://doi.org/10.1038/nature22355, 2017.

Taillefer, A., Soliva, R., Guillou-Frottier, L., Le Goff, E., Martin, G., and Seranne, M.: Fault-Related Controls on Upward Hydrothermal Flow: An Integrated Geological Study of the Têt Fault System, Eastern Pyrénées (France), Geofluids, 2017, 1-19, https://doi.org/10.1155/2017/8190109, 2017.

Taillefer, A., Guillou-Frottier, L., Soliva, R., Magri, F., Lopez, S., Courrioux, G., Millot, R., Ladouche, B. and Le Goff, E.: Topographic and Faults Control of Hydrothermal Circulation Along Dormant Faults in an Orogen, Geochem. Geophy. Geosy., 19, 4972-4995, https://doi.org/10.1029/2018GC007965, 2018.

Teixell, A., Labaume, P., and Lagabrielle, Y.: The crustal evolution of the west-central Pyrenees revisited: Inferences from a new kinematic scenario, Comptes Rendus Geoscience, 348, 257-267, https://doi.org/10.1016/j.crte.2015.10.010, 2016.

Ternois, S., Odlum, M., Ford, M., Pik, R., Stockli, D., Tibari, B., Vacherat, A., and Bernard, V.: Thermochronological Evidence of Early Orogenesis, Eastern Pyrenees, France, Tectonics, 38, 1308-1336, https://doi.org/10.1029/2018TC005254, 2019.

Valla, P. G., Rahn, M., Shuster, D. L., and van der Beek, P. A.: Multi-phase late-Neogene exhumation history of the Aar massif, Swiss central Alps, Terra Nova, 28, 383-393, https://doi.org/10.1111/ter.12231, 2016.

Vacherat, A., Mouthereau, F., Pik, R., Bernet, M., Gautheron, C., Masini, E., Le Pourhiet, L., Tibari, B., and Lahfid, A.: Thermal imprint of rift-related processes in orogens as recorded in the Pyrenees, Earth Planet. Sc. Lett., 408, 296-306, https://doi.org/10.1016/j.epsl.2014.10.014, 2014.
Vacherat, A., Mouthereau, F., Pik, R., Bellahsen, N., Gautheron, C., Bernet, M., Daudet, M., Balansa, J., Tibari, B., Pinna Jamme, R., and Radal, J.: Rift-to-collision transition recorded by tectonothermal evolution of the northern Pyrenees: cooling history of the northern Pyrenees, Tectonics, 35, 907-933, https://doi.org/10.1002/2015TC004016, 2016.

Van der Zwaan, B. and Dalla Longa, F.: Integrated assessment projections for global geothermal energy use, Geothermics, 82, 203 211, https://doi.org/10.1016/j.geothermics.2019.06.008, 2019.

Vergés, J., Millán, H., Roca, E., Muñoz, J. A., Marzo, M., Cirés, J., Bezemer, T. D., Zoetemeijer, R., and Cloetingh, S.: Eastern Pyrenees and related foreland basins: pre-, syn- and postcollisional crustal-scale cross-sections, Mar. Petrol. Geol., 12, 903-915, https://doi.org/10.1016/0264-8172(95)98854-X, 1995.

Vermeesch, P.: HelioPlot, and the treatment of overdispersed (U-Th-Sm)/He data, Chem. Geol., 271, 108-111, https://doi.org/10.1016/j.chemgeo.2010.01.002, 2010.

Volpi, G., Magri, F., Frattini, P., Crosta, G. B., and Riva, F.: Groundwater-driven temperature changes at thermal springs in response to recent glaciation: Bormio hydrothermal system, Central Italian Alps, Hydrogeol. J., 25, 1967-1984, https://doi.org/10.1007/s10040-017-1600-6, 2017.

Wanner, C., Waber, H. N., and Bucher, K.: Geochemical evidence for regional and long-term topographydriven groundwater flow in an orogenic crystalline basement (Aar Massif, Switzerland), J. Hydrol., 81, 124374, https://doi.org/10.1016/j.jhydrol.2019.124374, 2019.

Whipp, D. M. and Ehlers, T. A.: Influence of groundwater flow on thermochronometer-derived exhumation rates in the central Nepalese Himalaya, Geology, 35, 851, https://doi.org/10.1130/G23788A.1, 2007.

Whitchurch, A. L., Carter, A., Sinclair, H. D., Duller, R. A., Whittaker, A. C., and Allen, P. A.: Sediment routing system evolution within a diachronously uplifting orogen: Insights from detrital zircon thermochronological analyses from the South-Central Pyrenees, Am. J. Sci., 311, 442-482, https://doi.org/10.2475/05.2011.03, 2011.

Wölfler, A., Kurz, W., Danišík, M., and Rabitsch, R.: Dating of fault zone activity by apatite fission track and apatite (U-Th)/He thermochronometry: a case study from the Lavanttal fault system (Eastern Alps): Dating of fault zone activity, Terra Nova, 22, 274-282, https://doi.org/10.1111/j.1365-3121.2010.00943.x, 2010.

Wu, L., Monié, P., Wang, F., Lin, W., Ji, W., Bonno, M., Münch, P., and Wang, Q.: Cenozoic exhumation history of Sulu terrane: Implications from (U-Th)/He thermochrology, Tectonophysics, 672-673, 1-15, https://doi.org/10.1016/j.tecto.2016.01.035, 2016.

Zeitler, P. K., Enkelmann, E., Thomas, J. B., Watson, E. B., Ancuta, L. D., and Idleman, B. D.: Solubility and trapping of helium in apatite, Geochim. Cosmochim. Ac., 209, 1-8, https://doi.org/10.1016/j.gca.2017.03.041, 2017. 